\title{
ANTONIO BERGNES DE LAS CASAS, UN EDITOR PARA TODOS. DE LOS PRIMEROS PASOS EN EL GREMIO A EL MUSEO DE FAMILIAS (ÍNDICES)*
}

\author{
Dolores THION SORIANO-MOLLA \\ dolores.thion@gmail.com \\ Université de Pau et des Pays de l'Adour \\ «Y qué sería la vida humana, \\ si no soñáramos dormidos o despiertos» \\ (Antonio Bergnes de las Casas, 1873)
}

\section{Resumen}

Antonio Bergnes de las Casas fue un filantrópico vulgarizador de conocimientos y de literatura muy influido por la cultura cuákera inglesa. El presente estudio propone un recorrido desde sus primeros pasos en el gremio en tanto que editor de libros y periódicos hasta la fundación de El Museo de Familias (1838-1841), por su contribución a la creación de un espacio cultural europeo. En él anteponía los conceptos de ilustración y vulgarización en aras a «la felicidad del hombre» a los de creatividad y de originalidad en la revista. Por ello, ofrecía conocimientos prácticos y «aplicables a las primeras necesidades de la vida» para la educación del pueblo español.

Palabras clave: Antonio Bergnes de las Casas, El Museo de Familias.

\begin{abstract}
Bergnes Antonio de las Casas was a philanthropic popularizer of knowledge and literature, heavily influenced by English Quaker culture. This study proposes a journey from his first steps in the guild as a publisher of books and periodicals to the founding of the Museum of Families (1838-1841), with a special focus on his contribution to the creation of a European cultural space. In the magazine, he put the concepts of

\footnotetext{
* Este trabajo se inscribe en el proyecto de investigación ROMANTICISMO ESPAÑOL E HISPANOAMERICANO: CONCOMITANCIAS, INFLUENCIAS, POLÉMICAS Y DIFUSIÓN (FFI2011-26137), financiado por el Ministerio de Economía y Competitividad del Gobierno de España.
} 
enlightenment and popularization in the interests of «the happiness of man» before creativity and originality. For him, it offered practical knowledge, «applicable to the basic needs of life» and whose aim was the education of the Spanish people.

Keywords: Antonio Bergnes de las Casas, El Museo de Familias.

Si se ha recordado a Antonio Bergnes de las Casas (1801-1879) es sobre todo como eminente helenista y divulgador de las culturas clásicas en España. Su perfil polifacético, como rector de la Universidad de Barcelona, periodista, miembro de la élite cultural catalana, traductor y escritor han contribuido a acrecentar el olvido de sus facetas de librero y de impresor en Barcelona, tal vez por considerarlas más prosaicas. No obstante, contamos con dos trabajos fundamentales sobre su trayectoria como humanista y editor de libros (Olives 1947, Clua 1995) en las que se ha hecho acopio de los pocos materiales de primera mano que sobre Antonio Bergnes se conservan, aunque por el carácter generalizador de ambos estudios, siguen existiendo todavía lagunas sobre los múltiples quehaceres de esta personalidad tan inquieta como relevante del romanticismo catalán y sobre su labor como difusor de la cultura europea y universal en España.

El amor de Antonio Bergnes de las Casas por la cultura clásica, ciertas diferencias sociales de origen familiar y su trayectoria juvenil lo distancian de otras figuras representativas de la cultura catalana decimonónica. Es cierto que durante su juventud, Antonio Bergnes Bonaventura no siguió el mismo itinerario que otros universitarios como Carlos Aribau o Ramón López Soler. De hecho, por no ser colaborador de estos jóvenes inquietos, fundadores de La Sociedad filosófica y colaboradores de El Europeo, se suele atribuir a Bergnes una ideología conservadora y se le achaca un curioso distanciamiento respecto del movimiento romántico. Aunque a diferencia de los escritores considerados hoy como pioneros románticos, él siguiese un itinerario en un principio autodidacta, no por ello vivió aislado en una ciudad en plena efervescencia política como era Barcelona, ni al margen del liberalismo y de los inicios del romanticismo en la ciudad condal (Segalá 1916, págs. 27-28; Olives 1947, págs. 18-19). Afirma Santiago Olives, su principal biógrafo, que durante el Trienio Constitucional Antonio Bergnes formó parte de la Milicia Nacional y que simpatizó con la oposición fernandina, sobre todo con los exiliados (Olives, 1947, págs. 20-21)1․ Por otra parte, tanto los libros que tradujo, que escri-

1. Asimismo publicó La verdad sobre la República Federal (Barcelona, T. Gorchs, 1872) y El progreso, con algunas consideraciones históricas, filosóficas y políticas (Barcelona, Oliveres, 1873), ambas de ideología progresista. 
bió o que editó como las publicaciones periódicas que fundó son testimonio de unas inquietudes personales acendradamente románticas. Ello no era óbice para que en política apelase siempre a la moderación, a la reforma gradual de la sociedad frente a cualquier aniquiladora revolución, y, en literatura, conciliase su amor por la cultura clásica y los conceptos de imitación y de belleza con un romanticismo de corte historicista. Dentro de los límites cronológicos impuestos, nuestro trabajo se limitará a una sucinta revisión de la labor de Antonio Bergnes como filantrópico vulgarizador de conocimientos y de literatura, desde sus primeros pasos en el gremio en tanto que editor de libros y periódicos hasta la fundación de El Museo de Familias (1838-1841) por su contribución a la creación de un espacio cultural europeo.

\section{Primeros pasos en el gremio de impresores: edición y filantropía}

Llegar a ser editor desde 1828 y además de prensa periódica durante la Década Omniosa era un hito si de antemano no se pertenecía al gremio de impresores. Desde 1815, la familia Brusi se había hecho con el privilegio real de editar periódicos en Barcelona, por lo que durante los años de mayor represión y a excepción del paréntesis del Trienio Liberal escasas cabeceras vieron la luz en Barcelona hasta 1833 aparte del Diario de Barcelona, propiedad de aquella familia (Comas 2009, Guillaumet 2003). En el ámbito editorial, Barcelona contaba con casas acreditadas como las de Roca y Gaspar, de Piferrer o de Brusi, entre otras; pero, con la aparición de nuevos impresores Barcelona se convirtió, ya en puertas del reinado de Isabel II, en un núcleo fundamental de la producción editorial española e hispanoamericana.

Bergnes de las Casas empezó su andadura profesional en el ámbito del comercio, en los escritorios de Gironella y Ayguals - junto con Wenscelao Ayguals de Izco, de quien fue buen amigo- y de Estanislao Reynals. Allí aprendió pronto idiomas para atender la correspondencia extranjera ${ }^{2}$ y dio sus primeros pasos en el descubrimiento de la lengua y la cultura helénicas. $\mathrm{Al}$ parecer pronto empezó también a dar clases de idiomas.

Se dispone de poca información sobre Antonio Bergnes en su período juventud, en particular, de 1823-1828. Anduvo viajando por Francia, Inglaterra y Alemania. Al parecer, pasó bastante tiempo en Londres, donde se relacionó con cuáqueros que ejercieron notable influencia en su concepción filantrópica y espiritual de la vida. En 1828 regresó a Barcelona y su vida se estabilizó al contraer matrimonio. Prosiguió sus actividades como profesor y

2. Trabajo que el mismo Aribau realizaba también para Salvador Forés i Basart (Ferrer 1987, pág. 756).

Anales, 25, 2013, pp. 341-382 
traductor e inició su labor como publicista, influido por Henry Brougham y William Allen, fundadores de la londinense Society for the Diffusion of Useful Knowledge (Olives 1947, págs. 22-23). El objetivo de dicha sociedad era facilitar el acceso a la cultura a las clases desfavorecidas, adaptando los contenidos científicos y especializados para que fuesen asequibles para un público autodidacta o con poca formación escolar. Sin gran demora, a finales de 1828, Bergnes siguió las pautas de la Society for the Diffusion of Useful Knowledge. Empezó fundando la Biblioteca de Conocimientos Humanos. A finales de 1828 salieron a la luz las primeras entregas con una traducción del inglés del Discurso sobre los objetos, ventajas del saber y ensayos divulgativos y didácticos sobre cuestiones mecánicas, químicas y físicas varias, tales como la energía calórica, la acción de la fuerza de gravedad y los sistemas de poleas entre otros. Hacia 1829 creó una Sociedad Literaria, la cual figura como responsable del Diccionario Geográfico Universal, siguiendo el modelo de Mr. Mullebrum y los diccionarios europeos más modernos de la época. («Avisos», Diario Mercantil de Cádiz, 13-12-1829, pág. 8). Figuraron como redactores y miembros de dicha Sociedad Antonio Bergnes, Bernardo Agustín de las Casas, Juan Antonio Suárez, José Forés y Lorenzo Miguel. Tanto la Biblioteca de Conocimientos Humanos como el Diccionario Geográfico Universal los editó en la imprenta de José Torner de Barcelona.

Para Antonio Bergnes de las Casas esas primeras empresas como publicista debieron resultar eficaces y fructuosas porque enseguida fue diversificando su quehacer editorial, pese a las hostilidades de un medio tan cerrado como era el del gremio de impresores y editores. Merced a la ayuda financiera de su padre se lanzó a la traducción de obras literarias extranjeras de insignes escritores. «Ayer me dijeron que tu amigo Bergnes va a publicar el Ivanhoe que ya tiene la licencia del Juzgado», escribía Ignacio Sanponts a Bonventura Aribau (Carta de 22-VII-1829), cuando estos — asociados a Narciso Menard- estaban fraguando el proyecto de las traducciones de Walter Scott (Olives, 1947, págs. 25-26; Ferrer, 1987; Freire, 2005). No era falsa la noticia. En 1929 Bergnes ya tenía preparada y autorizada su traducción de Ivanhoe. Aribau que estaba preparando la misma obra, traducida por Ramón López Soler y por Juan Nicasio Gallego, no quiso asociarse a él. Sin duda el concepto de traducción que tenía Aribau del embellecimiento de la lengua de llegada como criterio esencial en la traducción se alejaba de la perspectiva mucho más comunicativa, divulgativa y amena, que prevalece en las versiones que Bergnes realizaba. En carta a López Soler del 17 de diciembre de 1828 argumentaba Aribau al respecto:

He recibido la carta del amigo Bergnes a quien contesto. No dudo que pudiera sernos de alguna utilidad: pero la diversidad de lenguas en que con tanto 
acierto se ha ejercitado hace que su castellano no sea del más correcto y castizo: así soy del parecer de que reservemos su cooperación para otras cosas que exijan menos aquellas cualidades, y esto aún sujetándole a una castigada corrección. Hoy le escribo alegándole varias causas que existen realmente y nos privan de admitir sus estimables ofrecimientos. ¿Te parece buena idea la traducción de Gessner? La prosa pudiera traducirla él y los versos nosotros en vista de su prosa literal y de las traducciones que existen en otras lenguas (Archivo Histórico de Catalunya, Olives 1947, pág. 25; Freire 2005, pág. 10).

Sin embargo, en años posteriores se ha reconocido las excelentes cualidades de Bergnes para las traducciones del griego clásico, por razones precisamente contrarias a las que aducía Aribau para las lenguas modernas: «dotes intelectuales y estéticas, honradez literaria, conocimientos de los idiomas que traducía, y un excelente verbo» (Clua 1995, pág. 28).

En 1931, con el apoyo de la Sociedad Literaria y en particular de Agustín de las Casas, primo y socio capitalista, Antonio Bergnes abrió las puertas de su «Imprenta Antonio Bergnes y Cía». Bergnes instaló sus propios talleres con maquinaria inglesa de alta calidad y nombró a Manuel Rivadeneyra, el futuro editor, como encargado del taller. Joaquín Rubió y Ors afirma que Bergnes contó con el apoyo de personalidades de gran poder, sin las cuales no hubiese logrado vencer tan fácilmente las barreras que los Gremios establecían a toda persona ajena y novicia que intentase ingresar en ellos (Rubió y Ors 1887, pág. 28, en Olives 1947, pág. 26).

Para constituir rápidamente su fondo editorial, Bergnes siguió imprimiendo la Biblioteca de conocimientos humanos y lanzó la colección de la Biblioteca Selecta, portátil y económica, también conocida como Biblioteca de Novelas Escogidas. Dicha Biblioteca reunía tres series que a todas luces buscaban un público lector amplio y variado. La colección gozó de notable acogida. Como indicaba la reseña de Cartas españolas Bergnes, a diferencia de otros editores, demostraba con ella que no consideraba tenía la literatura «como especie inútil más perjudicial que provechosa» («Publicaciones recientes», Cartas españolas, 16-8-1832, págs. 195 y 27-9-1832, págs. 372-375). La primera serie de la Biblioteca de Novelas Escogidas recogía clásicos españoles y es la que más pronto se enriqueció con obras exentas de derechos de autor, en especial las de Miguel de Cervantes, escritor por quien Bergnes sentía gran admiración. La segunda serie fue dedicada a traducciones de obras extranjeras aunque el proceso de adquisición de licencias era lento. La mayoría de las traducciones eran de escritores románticos europeos. Recordemos como botón de muestra El monasterio de Santa María (1832), El sarraceno (1832) y Abdallah (1832) de Chateaubriand, El enano misterioso (1832) de Walter Scott. Para la tercera serie reservaba Bergnes obras selectas de autores contemporáneos. Ahí salieron 
a la luz Las señoritas de hogaño y las doncellas de antaño (1832), adaptado de Eugenio Scribe por Ramón López Soler, como también su Jaime el Barbudo, o sea, la sierra de Crevillente (1832) o El Epicúreo (1832) de Thomas Moore. Eran todas ellas obras novedosas y de calidad, aunque la belleza de las traducciones fue uno de los aspectos que más críticas suscitó, sobre todo, en aquellas voces, como las de Cartas españolas, que consideraban que la novela era lectura inútil y había que dar a conocer la literatura nacional ( «Publicaciones recientes, Cartas españolas, 16-8-1832, págs. 193). Bergnes también introdujo en su fondo editorial las producciones teatrales, traducidas como El colegio de Tonnington (1831) de Víctor Ducange u originales, como Hermenegilda o el error funesto. En 1833 creó una Biblioteca de Damas o «nuevo periódico consagrado particularmente al bello sexo, útil por su doctrina, agradable por su amenidad» y moral, según rezaba su anuncio. En tan femenina biblioteca salieron a la luz las obras de Walter Scott y de James Fenimore Cooper. En realidad, este modelo de «periódico» era un opúsculo compuesto con novelas por entregas que salía tres veces al mes.

Si las obras que la librería Bergnes publicaba gozaron pronto de excelente crédito, era porque sabía «imprimir buenas cosas y en bella estampa, y con todo ello vender a precio cómodo». Con su fondo editorial se le integraba en los anales de la edición española, junto con «los Sanchas, los Ibarras, y los Canos» y se hacía loa de los méritos públicos de sus empresas («La trompeta literaria», Revista española, 5-12-1832, pág. 8). Las mismas características ofertaron las publicaciones periódicas que fundó Antonio Bergnes, actividad a la que se dedicó durante unos cuarenta años de su vida, a partir de 1831. Sus cabeceras fueron y han sido harto conocidas: El Vapor (1833-1835), el Museo de familias (1838-1841) y La Abeja (1862-1870).

En 1831 tal vez fuese el espíritu inquieto de Bonaventura Carles Aribau y Ramón López Soler quienes promovieron el lanzamiento de Antonio Bergnes al periodismo. En agosto de aquel año solicitó la licencia para publicar El Vapor (González 1933, págs. 17). Eulalia Brusi luchó para conservar el Real Privilegio de exclusividad de editar el único periódico existente en la capital condal, el Diario de Barcelona. La familia Brusi poseía dicho privilegio desde 1809 — había sido ratificado en 1816 y en 1824 y en 1930-, de modo que el diario salió a la venta sin interrupción a pesar de los avatares históricos (Guillamet 2003, págs. 242-243)3. Sin grandes dificultades Brusi obtuvo el mantenimiento de su privilegio en agosto de 1831 e incluso logró que se dictara la

3. Junto con dos periódicos científicos: el Diario General de las Ciencias Médicas (18261833), interrumpido unos añs por la publicación de Anales de Nuevos Descubrimientos (1828-1829). 
prohibición publicar noticias políticas ni cualquier cosa relativa a la familia real sin previo permiso. No por ello abandonó el proyecto Bergnes, quien volvió a presentar su solicitud a la Real Audiencia de Cataluña. En su prospecto, el editor anunciaba El Vapor como un periódico con una misión divulgadora, comprometido con el deber de difundir nuevos conocimientos a todas las clases sociales. Si bien los temas científicos y económicos eran dominantes, la literatura no faltaba en su programa:

Noticia y crítica de las obras que se publiquen en España y en el extranjero, siendo éstas de lícita leyenda.

Crítica teatral de las compañías española o italiana.

Trozos escogidos de los mejores autores clásicos en obra y en verso. (Prospecto de El Vapor. Diario científico, literario, económico y mercantil de Barcelona, González 1933, págs. 18-19).

Se suele afirmar que fue Aribau quien solicitó la ayuda del poderoso banquero Gaspar de Remisa - para quien trabajaba ya en Madrid - con el fin de que intercediese a favor de Bergnes, pero en realidad no fue así. El capitán general de Cataluña era entonces Manuel Llauder y Comín. A él se dirigió directamente Aribau para recomendar a Bergnes, según demuestran las cartas que sus herederos conservan y de las cuales dio noticia el Marqués del Valle de Rivas en ABC, el 17 de noviembre de 1968 y en El Noticiero Universal el 26 de abril de 1984. Ignoramos cuál ha sido el paradero de estas cartas. Entre los fragmentos que se citan —en una carta fechada el 2 de enero de 1831 en lugar de $1833^{4}$ Manuel Llauder y Comín transcribe las siguientes palabras de Aribau:

Con esta ocasión no puedo menos de felicitar a V. E. por el merecido entusiasmo que causa su presencia en esas provincias. Todos los amantes del orden nos congratulamos por el bien que en V. E. posee nuestra patria. Me permitirá V. E. que me tome la libertad de encomendar a su protección la imprenta de don Antonio Bergnes y $C^{a}$., de esa ciudad, en la que estoy interesado. Es en su clase el mejor establecimiento que existe en España. Sólo necesita una mano tutelar, y si V. E. gusta de servirse de él para las Secretarías y oficinas que de V. E. dependen, quedará satisfecho del desempeño. Bergnes, además, es un joven ilustrado y cuando convenga a las superiores miras de V. E. puede por un periódico o por otro medio encaminar por el buen carril la opinión pública (Carta de Bonaventura Carles Aribau a Manuel Llauder, Marqués de Valle de Ribas, 17-11-1968, pág. 6; Llauder 1893)

4. Incluso el 14 de diciembre de 1832 la Audiencia denegó la autorización de publicar otro periódico al impresor Tomás Gaspar de Barcelona (González 1933, págs. 21-22) y en su informe seguía citándose la negativa dada a la solicitud de Bergnes. 
Aribau dio muestras de agradecimiento unos días después, según informa el bisnieto de Manuel Llauder en el citado artículo:

Doy a V.E. las gracias por el apoyo que se ha servido dispensar a mi amigo Bergnes sobre el asunto del periódico para el cual S. M. ha tenido a bien conceder el permiso... V. E. ha hecho cuanto estuvo de su parte, y, aún, repito, el agradecimiento que siempre conservará éste, su affmo. Servidor, q. e. s. m., Buen $^{a}$. Carlos Aribau (Carta de Bonaventura Carles Aribau a Manuel Llauder, s.d., Marqués de Valle de Ribas 1968 y 1983).

El nuevo informe fue realizado al parecer por Manuel Llauder, quien se mostró favorable y buscó una alternativa a las exigencias de la viuda de Brusi. El privilegio se le otorgó para un periódico, que precisamente no fuera un diario, por lo que El Vapor se publicaría sólo tres veces por semana - martes, viernes y sábado- y no podría publicar los avisos locales. De este modo se respetaba al histórico Diario de Barcelona y, como escribía Llauder,

cumplía su deseo de no perjudicar en manera alguna el derecho a la propiedad y, por otra parte, no defraudar al público de las luces que tanto pueden contribuir al adelantamiento de las artes y del Comercio de esta capital (Guillamet 2003, pág. 243).

El Vapor salió a luz poco después, el 22 de marzo de 1833 y con él iniciaba Antonio Bergnes su trayectoria como editor de publicaciones periódicas románticas, vulgarizadoras del saber y símbolos del progreso. El periódico se publicó en su imprenta hasta abril de 1835, momento en el que Manuel Rivadeneyra se independizó y se llevó el periódico a su propia imprenta. Coincide este hecho con el exilio a Francia de Ramón López Soler y el cambio de dirección de El Vapor, convertido ya en diario, en manos de Felipe Monlau hasta 1836.

Prácticamente coetánea a El Vapor es digna de mención la colección que Antonio Bergnes tituló El nuevo viajero universal en América. Se trata de una serie de Historia de viajes en tiradas numeradas sobre las Antillas (1832), Méjico (1832 y 1833), Bogotá (1832), Perú (1832 y 1833) y América en general (1833). Son compendios de otras obras y las solían firmar M. y E. Con estos títulos Bergnes fue engrosando su catálogo y materializando su proyecto filantrópico. Si años después consideraba a España ya más europea en su Discurso sobre instrucción pública y los diversos métodos de enseñanza (1847) era, en parte, gracias a la labor divulgativa de este tipo de volúmenes. «Ya no posible que un estado europeo se encierre y aísle como en otro tiempo»-escribía Bergnes- porque:

Los extranjeros y viandantes a quienes, como episodios, desterraba Licurgo de las unidades dramáticas de su república, van recorriendo ahora, bajo el nombre de libros, todos los países. De ahí que ya no hay estado solo, aunque sea 
una isla situada en mares remotos. Los libros forman una república universal, una confederación de todos los pueblos... (Bergnes 1847, Clua 1995, pág. 47).

Materialmente, la concepción de El nuevo viajero universal en América se aproxima a la de la publicación periódica, ya que los problemas que el privilegio de edición de periódicos creaba debieron determinar su diseño más libresco. Se dirigía a un público sobre todo peninsular, poco después de que el Imperio se quedara reducido a Cuba y Puerto Rico en el continente americano. Anotemos por otra parte que los volúmenes de El nuevo viajero universal en América llenaron el hueco que el proyecto de El Vapor fue dejando durante el lento proceso de las autorizaciones y que desaparecieron cuando se publicó el periódico. Valga señalar la coincidencia, aun cuando puede que la desaparición de El nuevo viajero universal se deba a circunstancias ajenas al lanzamiento de El Vapor.

En tanto que sucesor de El Europeo, se suele considerar El Vapor como segundo periódico romántico de nombradía y, simbólicamente, ha llegado incluso a constituir el mito de los orígenes de la Renaixença catalana merced a la publicación de la «Oda a La Patria» de Aribau, el 24 de agosto de $1833^{5}$. Habían pasado ya casi diez años desde que desapareció El Europeo y si el romanticismo estaba calando lentamente en la prensa publicada en Barcelona no es porque se habían exiliado los exiliados italianos que contribuyeron a su impulso. El contexto no era favorable a un desarrollo más continuo del mismo en este medio de comunicación de masas controlado, como ya se ha observado, con privilegios reales y mediante la censura, a pesar de que esta fuese más permisiva con la hoja efímera de la prensa que con la edición libresca.

El periódico El Vapor, pese a su carácter todavía algo rudimentario, proponía una presentación gráfica esmerada. Su línea y diseño se asemejan a la de su antecesor El Diario Constitucional de Barcelona, periódico que fue prefigurando a El Europeo, pero que se suele olvidar. Como estudiamos en otro lugar, lo publicaron un grupo de amigos de la Sociedad Filosófica durante el Trienio Liberal, entre los que destacan los nombres de Aribau y de López Soler. Las secciones de estos periódicos son prácticamente las mismas y atienden a la actualidad política, la ciencia y la literatura. Destaquemos entre las secciones comunes la titulada A Ambos Mundos en la que se recogían puntuales noticias y recensiones de otros periódicos tanto de Europa como de Hispanoamérica. Tanto Aribau como López Soler gozaban ya de cierta pericia en la prensa periódica. Habían iniciado su trayectoria en el Periódico erudito de la Sociedad

5. Sobre el análisis del proceso de configuración de este mito es relevante el estudio de Ferrer (1987). 
Filosófica (1815-1816), que era manuscrito y en el que aparece ya el motivo del vapor como símbolo del progreso ${ }^{6}$, así como de El Europeo. Entre sus colaboradores habituales destacaban los nombres Wenceslao Ayguals de Izco, Mariano González, Pedro Matza, Antonio Robot, José LLausas, Josep Andreu Fontcuberta — que firmaba José Andrew Covert-Spring-, Milà i Fontanals, Pere Mata, Ribot i Fontseré y Sinibaldo de Mas.

Resulta difícil calibrar la impronta que cada colaborador deja en este tipo de publicaciones cuando prevalece una visión colectiva del periódico o de la revista, y, ello, hasta que no aparece la figura del periodista con la consiguiente firma de las colaboraciones. No obstante, en tanto que propietario y aun habiendo cedido la dirección del periódico, Antonio Bergnes de las Casas tuvo forzosamente que creer en aquello que subvencionaba o, al menos, asumir las líneas generales de lo que su periódico defendía y que puntualmente sometía a la censura. No por nada el primer director fue el otro amigo del grupo, Ramón López Soler como ya hemos anotado. Se suele afirmar además que Soler volvió de Francia para asumir dicho cargo. Los indicios que hemos ido anotando apuntan, en consecuencia, a una presencia muy activa de Aribau en segundo plano, tal vez con mayor protagonismo del que se le ha concedido frente a Bergnes y López Soler en tanto que sus representantes públicos de El Vapor. Al margen de valoraciones poco cuantificables sobre el protagonismo de Bergnes y su personal romanticismo, cabe subrayar que El Vapor fue una publicación fundamental en su trayectoria de impresor. En primera instancia, le permitió cumplir sus objetivos altruistas y filantrópicos. El periódico se presentaba como portaestandarte de conciliación, de paz y de esperanza de bien. Sus objetivos, pragmáticos y utilitarios residían en:

Poner de manifiesto al negociante cuanto de más notable y provechoso acaeciere en el orbe mercantil y político, para que con más precisión y acierto pueda proceder al cálculo de sus operaciones, indicar al artesano los adelantos de las ciencias en su contacto con las aplicaciones artísticas; instruir al hacendado de los progresos que a cada paso hace la agricultura; y ofrecer de cuando en cuando al literato el cuadro de la literatura nacional y extranjera, la discusión de los puntos que más interesan a las ciencias, la crítica de las obras que se den a la luz, y de las piezas dramáticas que se juzguen acreedoras a ella (Prospecto, El Vapor, 22-3-1833).

6. De hecho, en el número 43 del mismo, se daba la expectante noticia de la entrada de un barco inglés de vapor en París (Sesión 47, día 48 agosto 1816). Asimismo, con una loa al vapor se inauguraba el primer número de la homónima revista e incluso se publicó el romance histórico «Al Vapor» atribuido al Duque de Rivas, a la sazón en el exilio, en el número 2 de El Vapor, del 23 de marzo de 1833. Sobre este romance del Duque de Rivas: Ferrer 1998, págs. 125-148. 
Pese a su calidad de periódico de actualidad en el que no se podía eludir la noticia y la recensión informativa de otras publicaciones periódicas, El Vapor se perfilaba con un carácter enciclopédico dentro de los límites de las cuatro páginas y entre abundantes noticias. El carácter instructivo que interesaba al editor se iría posteriormente materializando en sucesivas publicaciones puesto que en aquellas columnas, poca cabida tenían estudios exhaustivos sobre tan diversos temas junto a la ineludible notificación de la actualidad nacional y extranjera. Es evidente que el periódico además canalizó y sirvió de plataforma de propaganda para los libros que la imprenta de Bergnes fue dando a la luz, en especial durante sus dos primeros años de vida.

El periódico en su primera salida fue bastante ecléctico y desde un punto de vista literario, el neoclasicismo en el que se formaron sus escritores convivió junto con un romanticismo europeo, en especial de corte historicista, como demuestra por ejemplo su actitud reverencial hacia Walter Scott en detrimento de autores como Ossian y Byron ${ }^{7}$. En contra de lo que se ha afirmado respecto de Bergnes y, en términos generales, El Vapor ilustra perfectamente que ser un espíritu moderado, liberal, incluso progresista, no es correlativo con la ideología que se profesa. Desde nuestra mirada de presente e influidos por nuestras tendencias al rigor taxonómico, tal vez sorprenda que un escritor que escribe novela social o utópica como es Wenscelao Ayguals de Izco, publique en El Vapor artículos - firmados-en los que defiende, por ejemplo, La razonable imitación neoclásica (20, 4-5-1883), o pone en tela de juicio El Romanticismo (74, 7-9-1833), como también puede resultar sorprendente que escritores tan carismáticos como Carles Bonaventura Aribau, padre mítico de la Renaixença, escriba poemas de circunstancias en honor a los monarcas en el mismo periódico.

Porque la ausencia de autoría en los artículos no implica forzosamente pensamiento único y compartido en el periódico, como tampoco contradicción. Como tribuna de opinión y de vulgarización El Vapor recoge voces y puntos de vista diversos a modo de caja de resonancia de un presente en período de cambio, con sus diversos puntos de vista e incluso sus refutaciones. En ello reside la riqueza de todo periódico y aún más cuando se apuesta por proyectos de corte altruista. A falta de un vaciado y estudio de fondo del mismo que reservamos para otra ocasión, basta con recorrer los dos primeros años de trayectoria de El Vapor, cuando era propiedad de Bergnes y sus socios, para comprobar cómo las cuatro páginas de esta publicación sirvieron

7. Recuérdese en particular el artículo «Influencia de las obras de Walter Scott en las generaciones actuales», El Vapor, 98, 23-11-1933. 
de palenque para la difusión del romanticismo y de la cultura europea en España. Aquellos escritores abiertos a la producción europea pese a las opiniones refractarias y negativas de algunas revistas españoles. Del mismo modo censuraban a menudo la visión superficial y estereotipada que se tenía de los españoles en Europa, y el uso literario de que la Nación se hacía. Citemos a modo de muestra, las airadas críticas suscitadas por un melodrama estrenado en Londres en el que se pintaban las costumbres españolas, más cercanas a las «de los negros bozales de Mandinga» — censuraba el periodista- que a la realidad. De modo que con cierto encono continuaba su reseña en los siguientes términos sobre los clichés de los pueblos meridionales:

Cuatro quejas al sol de Nápoles y al calor de Andalucía, cuatro madrigales a las Ninfas de Venecia o de Sevilla, cuatro epigramas a condición baladí del italiano y a la hueca arrogancia del jaque andaluz; y cálale la patria de Rafael y Murillo, de Ariosto y de Cervantes. Ahora bien: este tejido de lugares comunes, de rasgos incoherentes, de pueriles necedades, se emplea para enmarañar un enredo entre asesinos guapos, mujercillas fáciles, lacayuelos entremetidos y gentes supersticiosas... ¿Y Y estos son los españoles? - Sí señor, los españoles. — ¿Pero cuáles? ¿Los de Despeñaperros, los de Madrid, los de Cádiz, los de la Pineda fosca? —Sin duda serán los últimos. —iAh! Pues entonces lícito nos sería pintar a los ingleses por los bárbaros que hacen trompis, o a los alemanes por los esquimales que fabricaban carbón en la Selva Negra (Crónica teatral, 57, 30-7-1833).

En lo que se refiere a literatura, mencionemos la presencia de las secciones Eco de la literatura nacional y extranjera y Crónica Teatral. En Eco de la literatura..., que no era de salida regular, la redacción ofrecía sus juicios críticos sobre algunas novedades editoriales. Allí se reseñó, por ejemplo, el volumen de Poesías de un solitario de Serafín Estébanez Calderón, bajo una mirada estética romántica. A juicio del crítico,

aquellas letrillas, odas, romances y sonetos fueron objeto de encomio por la libertad creativa de la que hizo gala el poeta, entregándose «a su propio genio, y no menos amable que el céfiro que riza en las noches de estío la blanda superficie de las ondas, pinta con sutilísimo pincel la vida de sus movimientos y la varia incertidumbre de sus colores» (Eco de la literatura nacional y extranjera, El Vapor, 4, 29-3-1933).

La sección Crónica Teatral fue una sección mucho más regular y fue el género al que mayor atención le prestó El Vapor al hilo de los estrenos en Barcelona. En general, se suele observar un acendrado gusto por el teatro de corte neoclásico, útil y moral, siguiendo el criterio del escenario como escuela de costumbres en la estela de las comedias moratinianas -El Duque de Pentiebre, Vicente Rodríguez de Arellano, 10, 12-4-1833; Don Dieguito de Manuel Eduardo de Gorostiza, 14, 20-4-1833-, y las traducciones que fueron llenando 
la cartelera de Barcelona -Oscar, hijo de Osián, de Ducis, a cargo de Juan Nicasio Gallego, 13, 19-4-1833 y El mozo de café o El espósito ilustre, también de Ducis, 28, 24-5-1833; Blanca y Montcasen de Arnault, 27-4-1833; Intriga honrada o El procurador de Picard, 22, 10-5-1833, por citar algunos títulos-, sin descuidar por ello la producción española, como por ejemplo la tragedia Pelayo de Quintana, «gloria nacional» que ilustra el «justo medio» pese a su «vehemencia trágica, oportuno vigor y sonoridad desnuda de afectación pindárica» (23, 11-5-1833), o el repertorio clásico español como testimonio de la riqueza de la literatura nacional. En general, los críticos de El Vapor hicieron alarde de curiosidad frente a las producciones sobre todo francesas, como ya ha estudiado el profesor Francisco Lafarga (Lafarga 2004, 2009) e italianas. Por ello, otro género que se ensalzó fue la ópera, en particular italiana, como exponente de una sensibilidad romántica en el que la «complicación, el artificio, desconocida amalgama de lo físico con lo moral», de los que era ejemplo Bellini. Identificaban también dichas cualidades en el pintor Migliara o el escritor Walter Scott, junto con lo «filosófico por demás, análogo al ímpetu de sus pasiones y al desorden de sus facultades individuales» (9, 9-4-1933; y sobre Il crociatto in Egitto de Meyerbeer, 16, 26-4-1833; L'Elizire d'amore y L'Esule di Roma de Donizetti, 30, 28-5-1833 y 108, 26-11-1833 respectivamente).

En lo que a creación se refiere, en El Vapor vieron la luz composiciones poéticas en general de circunstancias, en función de eventos reales y períodos festivos. Además de la célebre Patria en catalán de Aribau, compuesta en honor de Gaspar de Remisa (68, 24-8-1833), encontramos títulos como Jesús crucificado de Aribau (5, 5-4-1933) y Oda a a la muerte de Jesús - tema literario recurrente durante la Semana Santa- que El Vapor ilustra con su habitual eclecticismo, tanto con un soneto de Manzoni como con el recuerdo de la Oda de Lista sobre el mismo asunto (8, 6-4-1933). Respecto de la prosa, anotemos que El Vapor cultivó el cuadro y la escena de costumbres en la sección precisamente titulada «Costumbres» a partir de una breve anécdota ficticia en general (El profesor de pintura, 11, 13-4-1833; La sortija, 14, 20-4-1833; Don Pánfilo Bobalicón, 20, 4-5-1883; Ricote de cuatro días, 26, 18-5-1833; El matrimonio sentimental; 29, 25-5-1833; Memorias estudiantiles, 32, 1-6-1833), en la misma línea que los otros periódicos y revistas literarias de la época.

Tras 1835 la actividad de Bergnes como profesor se fue incrementando. En su editorial siguieron viendo la luz las obras de Scott, de Manzoni, de Rousseau, de Goethe, de Fournier, de Fenelon, de Madame de Genis, entre los extranjeros; de Cervantes, de José Fontcuberta, de Mor de Fuentes, de Menéndez Valdés, entre otros nacionales, si bien su producción atendió sobremanera los títulos especializados de temas variados, desde la estadística, 
las ciencias naturales y la historia hasta los manuales de estudio. Ese ecléctico maridaje de obras y disciplinas característico de su fondo editorial se reproducirá en su siguiente publicación periódica, El Museo de Familias.

\section{Prensa y cultura para todos: El Museo de familias (1838-1941)}

Bajo el título El Museo de las familias. Obra periódica, Antonio Bergnes de las Casas completaba su proyecto educativo y filantrópico en 1838, una vez más siguiendo las pautas de los trabajos de sus amigos londinenses, en particular, de Charles Knight presidente de la Society for the Diffusion of Useful Knowledge. Antonio Bergnes lanzó dicha revista u «obra periódica», a imagen de The Penny Magazine (1832-1845), la primera revista de carácter enciclopédico e ilustrada destinada a las clases medias en unos ambientes de signo liberal. Se le ha considerado la heredera y sucesora del proyecto ilustrado de la Enciclopedia por ofrecer gran variedad de conocimientos clasificados y acompañados con ilustraciones (Darnton 1982).

The Penny Magazine tuvo rápido e importante éxito porque se le consideraba una revista de gran utilidad para la educación popular, por lo que las imitaciones afloraron rápidamente en Europa y Estados Unidos. En Alemania, se tradujo de manera homónima Das Pfenning Magazine (1833-1835) y en Francia, sus equivalentes fueron Magazine Pittoresque (1833-1838) y el Musée des familles. Lectures du soir (1833-1900). Todas ellas compartían el mismo objetivo de dar a conocer los más variados temas, hasta entonces al alcance exclusivo de los hombres eruditos. Porque, como anunciaba Antonio Bergnes al lanzar El Museo de las Familias:

Entre los inventos modernos, ninguno más útil seguramente que el que pone al alcance del Pueblo los adelantos que han hecho las Ciencias, ilustrándole en orden a sus intereses, rectificando sus ideas equivocadas, y contribuyendo a su emancipación intelectual (Prólogo, El Museo de las Familias, 1838).

El público que querían captar era amplio; ya no sólo el consabido obrero - a la sazón jornalero— sino al «Pueblo» en general, en quien la literatura podía, a juicio del editor catalán, ejercer grandes beneficios a través de la imaginación y de la fantasía. En la línea de los proyectos cívicos ilustrados, pero sin elitismos y apelando al conocimiento sensible, con El Museo de las familias Bergnes se proponía elevar los niveles de instrucción y, en especial, la moralidad y el humanismo de sus lectores de ambos sexos. Desde la perspectiva ética, apolítica y en apariencia aconfesional de El Museo, el «Pueblo» para el editor no es sólo

el jornalero que en los días festivos puede dedicar algunas horas a la lectura de nuestro Museo, que en breve preferirá a los deleites groseros y perniciosos; 
es también el muchacho aprendiz, para quien este libro vendrá a ser un recreo instructivo, y quizás un freno moral; es además la soltera, la casada, la madre de familia, que preferirá nuestros escritos castos e interesantes a las novelas ocasionadas e impuras que pervierten y descarrían; es el comerciante, el labrador, el soldado, el artesano, el marino, que hallarán en estas páginas instrucciones y solaz; es sobre todo la niñez, cuya activa inteligencia está pidiendo a todas horas alimento sano y sabroso que forme su corazón (Prólogo, El Museo de las Familias, 1838).

Pese a que Antonio Bergnes no tuvo reparos en filiar gráficamente su revista con Musée des familles al utilizar su portada y maquetación, la línea editorial que él proponía para sus cuadernillos ${ }^{8}$ mensuales —en $4^{\circ}$ mayor de 8 pliegos en dos columnas, ilustrada con ricas láminas grabadas en boj- responde en mayor grado a la del original inglés. En efecto, Musée des familles es una revista de presentación más cuidada y prolija en ilustraciones que The Penny Magazine o que el Magazine Pittoresque —imitación cercana del original inglés-. Aunque en general la estructura compositiva es bastante semejante, las dos revistas francesas se distancian del modelo inglés por el carácter mucho más autóctono y menos universalista de sus contribuciones; o sea, que tienden a circunscribirse a la realidad, a la cultura y las preocupaciones francesas por lo que resultan lecturas más cercanas y tal vez más elocuentes para su público. Otro rasgo que las distancia del modelo inglés es la autoría de las contribuciones, la mayoría están rubricadas por sus escritores, asimismo de origen francés. Por todas estas características se deduce que las revistas francesas privilegiaban en mayor grado la creación y la selección de textos franceses evitando la servidumbre de las traducciones. No fue ese el criterio que rigió el quehacer de Antonio Bergnes. La organización de las secciones y de los contenidos de El Museo de las familias se asemeja sobremanera a The Penny Magazine. De ella recoge los epígrafes de modo que su carácter divulgativo, práctico y enciclopédico es más fiel al original inglés —o a Magazine pittoresque que Musée de familles-. De hecho, la creación literaria de la revista barcelonesa tiene menor representatividad que en todas ellas. «No se crea que sea una copia servil del que con este dictado se está publicando en Francia», aclaraba Antonio Bergnes en su citado Prólogo a El Museo de las familias, precisamente porque la traslación de aquellos contenidos poco interés podían despertar en el público lector español y porque su propósito era de editar una revista más «general y variado(a)», no tanto recabando originales españoles

8. Cada seis cuadernos constituían un tomo y en el último se entregaba el índice de todas las materias y títulos del tomo.

Anales, 25, 2013, pp. 341-382 
como nutriendo sus páginas de selectas traducciones de las obras periódicas de mayor nombradía que se están publicando en Europa:

La REVISTA DE EDIMBURGO, que es entre todas la más acreditada; las TRANSACCIONES FILOSÓFICAS y la ENCICLOPEDIA DE LA REAL SOCIEDAD DE LONDRES, LA REVISTA BRITANICA, la REVISTA DE PARIS, lOS ANALES DE VIAJES, LOS ANALES DE NUEVOS DESCUBRIMIENTOS EN ARTES Y OFICIOS; la Obra magnífica de FERRARIO, que contiene los monumentos, trajes, vistas, etc. de todos los pueblos del globo, y otras obras y manuscritos que sería largo de enumerar: tales son los materiales con que contamos para enriquecer la obra que anunciamos, y si a esto se agrega el realce de las láminas grabadas en boj por los más célebres artistas de Londres, París y Barcelona, fuerza será confesar que ninguna publicación de esta clase puede llevar a la nuestra ventaja (Prólogo, El Museo de las Familias, 1838).

Destacan además como fuentes las revistas London and Wenstmister Revue, British and Foreign Review, Quaterley Revue, Blackwood Magazine, Asiatic Journal, Trimestral Review, Musée des familles, según informan los artículos que de ellas fueron traduciendo en El Museo de las familias. Teniendo en cuenta el origen de todas estas fuentes, podemos afirmar que lo que distingue El Museo de las familias respecto de sus dos modelos más inmediatos es el estar compuesto esencialmente con un compendio de traducciones, y por el mismo motivo, su carácter extranjerizante: universalista, exótico y de notable americanismo cuando los artículos versan sobre ciencias naturales, sobre geografía y sobre viajes; en mayor grado europeísta en lo que se refiere a otros estudios científicos, a estudios morales, a historia y a literatura. Todo lo convertía Antonio Bergnes en atractivo y sugerente reclamo publicitario para futuros suscriptores, abriendo aquella cerrada España pirenaica y transportando a sus lectores a los parajes más curiosos y lejanos del globo y haciéndole descubrir extraordinarios eventos y novedades, extrañas costumbres y amenas realidades:

[...] a los áridos desiertos del África, a las frescas riberas del Ganjes, a los dilatados páramos y frondosas selvas de América, a las cumbres de los Andes, a las islas risueñas del mar del Sur, al asqueroso banquete del salvaje antropófago, a la caza del león, del tigre, del elefante; ora llamarán su atención los portentos de la industria, desde los toscos ensayos de los pueblos bárbaros hasta las colosales empresas que igualan hoy día los montes con el llano; ora contemplarán los fenómenos de la astronomía, física, etc.; ora quedarán embelesados con los estudios de historia natural, de donde se sacarán apólogos morales e interesantes; ora cautivarán su entendimiento las anécdotas y los estudios morales que se irán interpolando... (Prólogo, El Museo de las Familias, 1838).

Puesto que El Museo de las familias se componía según un criterio antológico —en vez del de la difusión de originales_, poco se sabe de sus colaboradores, 
salvo de los pocos que en ocasiones se citan o de quienes se reconoce la paternidad de textos o de grabados: Antonio Rovira y Trías, arquitecto catalán, que cedía breves textos sobre monumentos catalanes y sus respectivos grabados; Joaquín María Bover y Rosselló, historiador mallorquín; Antonio Rovira y Trías, arquitecto; Antonio Fargas, musicólogo; Antonio Furió, mallorquín especialista en Bellas Arte y miembro de la Academia de las Bellas Letras de Barcelona y José Mor de Fuentes, amigo de Antonio Bergnes. Son éstas las únicas firmas que aparecen en los cinco volúmenes de la revista, aunque se sabe que el editor también colaboró con traducciones y otros textos de crítica e historia de la literatura. Bergnes recurrió también a autores que conocía de antemano por haberlos seleccionado para su fondo editorial -recordemos al alemán Enrique Zschokke, traducido al francés por Loeve-Weimars-e introdujo nuevos escritores e intelectuales extranjeros, tales como Jean Paul Richter, Marceline Valmore, Víctor Cousin, George Owen, Thomas Carlyle, Alexis de Tocqueville, James Morier, Lady Blessington, M. Bocas, M. G. Morris, Félix Romani, y Fenimore Cooper. Tampoco faltaron los extractos de títulos de su propio fondo editorial: de las obras científicas de naturalistas como las del célebre ornitólogo Audubon a los viajes de Revaux en sus Consideraciones sobre la historia natural, las obras de carácter histórico como las de Romey y de Thiers hasta el Epítome histórico de Vicente González de Regnero que Antonio Bergnes incluyó en su edición de los Romances del Cid Campeador (III, 1840, págs. 340-354).

La visión extranjera está asimismo presente en las miradas especulares que los lectores de El museo de familias podían descubrir a través de las construcciones culturales que los alemanes habían realizado de la historia y la cultura españolas, como documentan algunos extractos en Bosquejo de la poesía española anterior al siglo de Carlos de Austria (II, 1839, págs. 324-330) basado en Silvas de viejos romances viejos (1815) de Grimm, Floresta de rimas antiguas castellanas (1821-1825) de Bohl von Faber y Sammlung der besten alten spanischen Romanzen (1817) de G.B. Depping's. A este último se debe también la serie de Romances del Cid Campeador arriba citada que El Museo de Familias publicaba de manera seriada a partir de junio de 1840. Se trata de una selección de romances que Depping había realizado de la Colección de los más célebres romances antiguos españoles, publicados en Altenburg en 1817 y por Bergnes en 1842, con prolijos grabados de José Gaspar y Miguel Torner que imitaban de los originales alemanes. Aparte de esa mirada que los escritores alemanes vertieron sobre la literatura española, encontramos algunas aportaciones autóctonas, aunque no son numerosas, en las que el lector podía reconocer su patrimonio nacional representado en algunas láminas y breves 
descripciones históricas — vid. índices en anexo-. Entre los escritores españoles de quienes la redacción de El Museo ofrece algunos apuntes biográficos, destaquemos las figuras de Miguel de Cervantes y la de Telesforo de Trueba y Cosío. Como representante de la literatura nacional y del genio español desde una perspectiva romántica, descuella la figura de Miguel de Cervantes (Miguel de Cervantes Saavedra, II, 1939, pág. 30) en pequeña y breve nota, probablemente de la pluma de Mor de Fuentes, quien había publicado un Elogio a Miguel de Cervantes y era asiduo colaborador de Bergnes. Respecto de Telesforo de Trueba se ofrece una biografía literaria en la que se rinde homenaje a su trayectoria como exiliado, víctima del despotismo español, y a su producción literaria en una lengua y para una sociedad ajenas a la propia.

Tasso, Schiller, Goethe, Hoffman, Morier o Lord Byron, como se puede observar en el índice adjunto, son las personalidades que destacaron entre los escritores, testimonio del carácter particularmente europeísta y extranjerizante de la literatura en El Museo de familias. Ahora bien, los relatos traducidos, desde las misceláneas, cuadros de costumbres, cuentos y novela por entregas son en particular de origen anglosajón debido a las fuentes utilizadas por Bergnes. La visión amena y moral cuáquera y protestante quedan sobremanera representadas en estos relatos que reflejan realidades distantes de las españolas e incluso catalanas. Familias, hombres y mujeres, viajeros, científicos, médicos, químicos entre tantos otros personajes de origen sobre todo inglés -y puntualmente alemán, ruso o chino- desfilan por estas páginas cosmopolitas y extranjerizantes de El Museo de las familias.

Antonio Bergnes anteponía los conceptos de ilustración y vulgarización en aras a «la felicidad del hombre» a los de creatividad y de originalidad en la revista (Los editores del Museo de familias a sus suscriptores, II, 1-5-1939). No por ello carecía el Museo de menor valor que otras publicaciones periódicas, porque para Bergnes, bastante visionario, primaba la comunicación sobre todo en un país tan rezagado como España, consecuencia del peso de su historia inmediata. En consecuencia, el Museo tenía unas finalidades pragmáticas que se enmarcaban en el proyecto de reforma de España en el ambiente de libertad de pensamiento y religión que auspiciaba la regencia isabelina; su destinatario principal, o al menos al que quería seducir, era el pueblo. Porque era consciente de las dificultades materiales -el tiempo y el dinero-, el Museo de las familias respondía a ellos con estas publicaciones por entregas y baratas que ofrecían conocimientos prácticos y «aplicables a las primeras necesidades de la vida», y que podían abrir puertas a otras necesidades educativas y culturales menos urgentes a la sazón (Al público, los editores del Museo de familias, III, enero de 1840). 
La revista gozó de gran éxito, pues a decir de Antonio Bergnes, contó en menos de un año con tres mil suscriptores, los cuales fueron en aumento hasta 1840. Por este motivo, el Museo pasó a ser mensual, a imitación de otros periódicos anglosajones y se estructuró en grandes secciones temáticas por disciplinas lo que le imprimía mayor solemnidad académica y rigor científico y cultural. Estos rasgos, sin embargo, no agradaron a sus lectores, por lo que en el segundo semestre de 1840, El Museo de las Familias volvió a su organización inicial suprimiendo entradas, como muestran los índices, relativas a los boletines de las academias y aligerando las de carácter científico, filosófico e histórico. Aunque la literatura quedaba en un segundo plano en este proyecto altruista y reformista, el tipo de discurso que utilizaba El Museo de las familias, ya fuese en textos científicos, históricos, filosóficos o de viajes, buscaba ante todo la amenidad y la facilidad. El docere y delectare horaciano primaban hasta el punto de seleccionar entre los textos aquellos pasajes más fáciles, más narrativos y testimoniales.

La curiosidad, el exotismo - de los cuatro rincones del mundo-, el carácter singular y extraordinario caracterizaron los artículos de El Museo. Los redactores solían recordar a los lectores dichos rasgos considerados como signo de originalidad, para estimular la lectura de textos de divulgación y cuadros domésticos cuya «autenticidad es indisputable». Estaban escritos en estilo sencillo — como los redactores pergeñaban en subrayar-, incluso a veces «sin pretensiones de autor» (Misceláneas. Memorias autobiográficas de una familia malaya, IV, 1840, pág. 21). Ese afán de acercamiento y de nivelación a un lector de poca formación era recurrente y dictó el estilo de El Museo, salvo en el segundo semestre de 1840, período en el que los textos tomaron un calibre algo más académico, como ya se ha anotado, a imagen de la distribución en secciones de la revista. En numerosas ocasiones los redactores presentan los textos en unas breves introducciones cuyo objetivo reside en crear un clima de confianza para animar a los lectores. Por ejemplo, a la hora de disertar sobre la epidemia de peste en Londres, el anónimo periodista se dirigía en los siguientes términos al lector:

No espere el lector hallar en este cuadro la historia o descripción de aquella espantosa catástrofe que en 1665 diezmó la población de Londres; sino una narración sencilla, escrita sin arte ni afectación, el conjunto de las circunstancias, muy vulgares, por cierto, que señalaron la existencia de una familia durante el desenlace de las vicisitudes del gran drama. La verdad y la posición de los personajes constituyen todo el mérito de esta relación (Un episodio de la peste de Londres de 1665, IV, 1840, pág. 55).

Estos hablantes periodistas desarrollan las funciones narrativas de los textos con intenciones didácticas, convirtiendo en relato el hecho, el dato o el 
documento a través de cuentos, autobiografías ficticias, relatos testimoniales, parábolas a modo de exempla tradicionales. Ya sea para dar vida a los estudios científicos, geográficos o de viajes, el estilo busca el contacto personal, cercano al lector como muestra el apelativo de la cita anterior. Siguiendo la tradición y el pragmatismo didáctico, el discurso se reviste de cierta oralidad atendiendo, obviamente, a la capacidad de recepción y de memorización del auditor durante la lectura en voz alta en familia o en los gabinetes. El acto de escritura se convierte incluso en gesto locutorio, en habla, y para ello se hace acopio de cualquier artilugio persuasivo para cautivar la atención del lector y se recurre a la personalización y humanización de los contenidos. Por ello, casi siempre es un personaje, en un contexto determinado y sometido a unos avatares mínimos precisos, quien trasmite los conocimientos deseados. Sobresalen asimismo los textos escritos en primera persona, en los que el personaje experimenta y a la vez reflexiona sobre su experiencia, entremezclando narración y diálogo para dar vivacidad a los textos. Todos estos rasgos abundan en la dimensión vivencial y sensible de acto de lectura y de apropiación de conocimientos.

Sea cual sea el tema o el argumento desarrollado, la perspectiva de los redactores de El Museo responde a los valores del pensamiento y de la estética románticos. Ya sea al tratar el tema de la Edad Media, en la estela de Walter Scott, incluso en estos textos de mayor o supuesta objetividad, no renunciará el escritor a «conservar sin afectación el tinte de candor que brilla en los autores desconocidos que nos han suministrado materiales para nuestra relación» (Edad Media española. Bernardo el Carpio, I, 1938, pág. 107). Aunque en el cuadro de costumbres dedicado a Bernardo el Carpio, El Museo se proponía remozar su figura siguiendo un criterio historicista supuestamente objetivo en el que se eliminase cualquier indicio novelesco para distanciarse de la crónica y de los romances, el periodista opta sin embargo por el anacronismo y el «tinte de candor» apostando por la capacidad de evocación y sugerencia del relato; o sea, por el conocimiento sensible. En la misma línea, cuando se trata de presentar alguna enfermedad en los apartados de Ciencias médicas, el periodista justifica su punto de vista y la metodología que adopta en la presentación, por ejemplo, del enajenamiento verbal, apelando de nuevo aquel tipo de conocimiento personal y subjetivo?.

9. El artículo empieza reaccionando en contra del ciego e irreflexivo empirismo: «Vamos a dar una ojeada sobre esta interesante enfermedad, y principalmente sobre las causas que la determinan o la desarrollan. No es nuestro intento cabal, minucioso, técnico. Nos limitaremos a reunir hechos, cuya exactitud podrán reconocer todos, apelando a sus recuerdos; pues en el fondo, son estas las únicas bases en que puede el hombre científico 
En general, como ya se ha observado en sucesivas ocasiones, conviven en las páginas de El Museo de familias los temas y valores de la sensibilidad romántica con los de la cultura clásica de Antonio Bergnes, pero también de Mor de Fuentes - más olvidado- en lo que a literatura se refiere si bien quien acabó firmando en el último volumen (La Pléyada española o los siete prohombres, V, 1841, págs. 303-310). En los artículos sobre literatura subyace el pensamiento filosófico y estético alemán, y en el concepto de literatura como espejo del alma — númen-y crisol de las civilizaciones occidentales. Aun teniendo en cuenta los particularismos nacionales la visión que suele ofrecer Museo de familias de la literatura y del arte en general es ya internacional e incluso universalista. Trátese del Progreso y de la decadencia de la pintura (IV, 1840), de la Comparación entre las literaturas de los diversos países del globo (IV, 1940), del Influjo que ha ejercido o está ejerciendo Walter Scott en la riqueza, la moralidad y la dicha de la sociedad moderna (I, 1938) o de las Mujeres griegas (I, 1938), entre otros títulos, no faltaron las referencias a la literatura como reflejo del carácter de los pueblos y de sus circunstancias históricas, pero sobre todo, a las interrelaciones, a las influencias, a las actualizaciones y a la evolución en una especie de cosmovisión europeísta de la cultura y del arte. Se compagina esta visión romántica de la literatura con la filantrópica, ya que se le atribuyen un didactismo capaz de educar moralmente a los lectores.

Valga este rápido recorrido por El Museo de las familias para poner de manifiesto la importante contribución de las revistas románticas a la creación de un espacio cultural y literario europeo avant la lettre y la visión moderna que los románticos tuvieron de la comunicación. A todas luces, El Museo de familias, por su carácter enciclopédico, fue una útil empresa filantrópica, pues Antonio Bergnes de las Casas estaba convencido de que la educación y la instrucción eran una «varilla mágica que, bien dirigida, ha de mejorar el aspecto del país, empleando en su ventaja el exceso de vida de la nación, que, por efecto de la ignorancia, se empleó en destrozarlo» (Bergnes 1847, Clua 1995, pág. 73).

Tras cinco años de existencia, el 1 de junio 1841, los editores de El Museo de Familias anunciaban el cese de la revista y su sustitución por El Album pintoresco español. Bergnes ocupó nuevos cargos y funciones académicas, pero aun así volvió a fundar un nuevo periódico o revista cultural de dimensión también europeísta. Como su título, La Abeja tenía asimismo como objetivo el polinizar con nuevos conocimientos, ideas, valores y sensibilidades el «destrozado» panorama cultural español.

edificar con seguridad» (Ciencias médicas. Del enajenamiento verbal, causas que lo producen, y remedios que lo curan, I, 1938, pág. 191). 


\section{ANEXO}

I- Vol. I, 1838

- Prólogo

- Estudios de Historia Natural, págs. 1-18.

- Viajes. Viaje de Lima a Para, por los Andes, las misiones y el río de las Amazonas, págs. 21-32

- Costumbres Inglesas. El regreso del Nabá, págs. 33-46.

- De la Hidrofobia y de los medios de precaver su desarrollo, págs. 47-51.

- Viajes. Terremoto en Chile, págs. 51-58.

- Mosaico de la Iglesia San Miguel de Barcelona, pág. 59.

- Sepulcro de Escipión en Tarragona, pág. 60.

- Ciencias Médicas. Del régimen dietético y de su influencia en la salud, págs. 61-70.

- Viaje al Polo Boreal, págs. 70-84.

- Don Juan, págs 84-94.

- Baños que existían en Barcelona en la calle del mismo nombre, pág. 95.

- El Soldado ruso y la joven armenia. Anécdota contemporánea, págs. 96-107.

- Edad Media española. Bernardo del Carpio, págs. 107-114.

- Fisiología. De la edad y de su influjo en la economía del hombre, págs. 114-118.

- Una caza de elefantes en las cercanías del cabo de Buena-Esperanza, págs. 118-121.

- Arco de Bará, cerca de Tarragona, pág. 122.

- La cena en casa de un nigromántico. Imitación de un cuento alemán, págs. 123-128.

- Cuadro de costumbres. La lonja de Londres, págs. 128-135.

- Expedición proyectada en los Estados Unidos para explorar los recursos comerciales de las Islas del Mar del Sur, págs.135-142.

- Viaje al Polo Boreal, págs. 142-153.

- Diario de un médico. El Boxer o el luchador y la Niña. págs. 153-170.

- La amistad, págs. 170-174.

- El utilizador. Anécdota americana, págs. 174-177.

- La caridad en el invierno, págs. 178-180.

- Filosofía. Los restos de Jacob, págs. 181-185.

- Puente del Diablo y arco triunfal cerca de Martorell, pág. 186.

- Proverbios orientales. Plutarco, Ley de Solón, pág. 186.

- Virgilio, Pelea de dos toros en celo. Geórgicas, pág. 187. 
- Ciencia médicas. Del enajenamiento mental, causas que lo producen y remedios que lo curan, págs. 191.

- Sala capitular del monasterio de Poblet, pág. 197.

- Historia de las sectas religiosas. Los cuaqueros. Los anabaptistas, págs. 198-206.

- Viajes. Tres días en las riberas del Orinoco, págs. 206-211.

- Diario de un médico. El comerciante arruinado, págs. 211-220.

- Estudios morales. Aventuras de una familia inglesa, cap. I y II, págs. 222-231.

- Literatura. Mujeres griegas, págs. 231-240.

- Ciencias Naturales. Observaciones sobre las principales clasificaciones del género humano, págs. 240-243.

- Costumbre húngaras. Speranski I, págs. 243-255.

- Historia. Situación del pueblo ruso desde sus orígenes hasta nuestros días, págs. 256-273.

- Estudios morales. Aventuras de una familia inglesa, cap. III-V, págs. 274-289.

- Diario de un médico. Deslie y arrepentimiento, págs. 290-300.

- Escenas de la Iglesia primitiva, págs. 300-304.

- Minerva. Catedral de Tarragona, pág. 305.

- Barcelona vista de la punta del muelle nuevo, págs. 306-308.

- La Maladeta. Junto a Venasque. Escenas de los Pirineos, págs. 308-317.

- Representaciones de Jovellanos. El esclarecido Jovellanos, perseguido de muerte por Godoy, y encerrado en la fortaleza de Belver, en Mallorca, dirigió a Carlos IV los escritos siguientes, que son dechado de sublime elocuencia y de castizo lenguaje, págs. 317-320.

- Geografía. Viajes. De los viajes más recientes alrededor del mundo, págs. 320-330.

- Diario de un médico. Deslie y arrepentimiento, págs. 331-339.

- Los lobos, págs. 339-344.

- Escenas de la vida militar. Una ejecución en la isla de Malta, págs. 344-349.

- El sepulcro de María, págs. 349-354.

- Influjo que ha ejercido y está ejerciendo Walter-Scott en la riqueza, la moralidad y la dicha de la sociedad moderna, págs. 354-359.

- Misceláneas. El último jefe de una tribu indiana. Anécdota americana, págs. 359-362.

- Las dos hermanas, págs. 362-369.

- Don Juan de Austria, págs. 371-372.

- Escenas irlandesas, págs. 372-378. 
- Economía política, De los diferentes sistemas de colonización, de sus causas y de sus resultados, págs. 379-383.

- Anfiteatro de Tarragona, pág. 384.

II- Vol. II, 1839

- Los editores del Museo de Familias a sus suscriptores. Aviso importante, pág. 6.

- Estudios de historia natural. Artículo II, págs. 7-17.

- Diario de un médico. El rico y el pobre, págs. 17-23.

- Cuadro de costumbres. Jorge de Lindsay, págs. 24-29.

- Miguel de Cervantes Saavedra, págs. 30-32.

- Moral. Fábricas de vicios y delitos al uso de los gobiernos. Fábricas de vicios y delitos al uso de los gobiernos (Babylon the Grese), págs. 33-41.

- Viajes. Un invierno en Laponia, págs. 41-47.

- Ingenios contemporáneos. D. Vicente Cuyás, págs. 48-49.

- Bajo relieve del claustro de la catedral de Tarragona, pág. 50.

- Ciencias naturales. Escenas de la vida de un naturalista, págs. 51-62.

- La Alhambra, págs. 63-64.

- Filosofía-Historia, - La Magia en el siglo XIX y en los anteriores, págs. 64-74.

- Diario de un médico. La Tisis, págs. 74-82.

- Gelina, págs. 82-92.

- Un matrimonio griego en Atenas, págs. 92-95.

- Escenas de la vida marítima. El Maelstrom, págs. 95-99.

- Estudios marítimos. De algunos animales apócrifos y fabulosos del mar, págs. 99-103.

- Historia contemporánea. Morris, M. G., Memorias, págs. 104-116.

- Murillo, págs. 117-118.

- San Miguel Desfal, págs. 118-119.

- Arqueología. Banquetes atenienses, págs.120-127.

- Usos y costumbres de los chinos, págs. 128-145.

- Ciencias médicas. De la combustión humana espontánea, págs. 145-150.

- Costumbres sicilianas, págs. 150-158.

- Diario de un médico. ¡Es loca...!, págs. 157-171.

- Viajes. Excursión a la Meca y a la Medina, págs. 172-179.

- Cardona, págs. 179-180.

- El Taso, pág. 181-190.

- Autobiografía. Juventud, locura y casualidad, págs. 191-201.

- De las casas de refugio en los Estados Unidos, págs. 201-204. 
- Ciencias médicas. Método seguro para mejorar la salud y alargar la vida, págs. 205-210.

- Viajes. Segunda expedición comercial a las costas de China, págs. 210-213.

- Literatura. Supersticiones poéticas de la Escocia, págs. 214-223.

- Diario de un médico. El desafío, págs. 223-228.

- Morier, James, Las consejas de Schiraz, págs. 226-337.

- El casamiento chino, págs. 237-239.

- Schiller, págs. 239-241.

- La corte de Madagascar, págs. 241-245.

- Los monjes del monte San Bernardo, págs. 245-247.

- Persecuciones contra el cristianismo, págs. 248-250.

- Vista de Monistrol y de la montaña de Montserrate, págs. 250-251.

- Los pongos, págs. 252-256.

- La caverna del tigre, págs. 256-259.

- Ciencias físicas. De los sonidos naturales y de su relación con el arte musical, págs. 259-267.

- Potencias intelectuales y nuestra edad. Humphrey Davy, págs. 267-272.

- Biografía. Vida y aventuras de Trelawney, amigo de Lord Byron, págs. 272-281.

- El sepulcro de Lord Byron en Hucknall Torkard, págs. 281-284.

- El cisne blanco y el cisne negro, págs. 284-286.

- El perro de Terranova, págs. 286-289.

- Los gemelos de Siam, págs. 289-291.

- Diario de un médico. La hija del comerciantes, págs. 291-301.

- Furió, Antonio, D. Guillermo Mesquida, págs. 302-303.

- Rovira y Trías, Antonio, Claustros de la Iglesia de San Pablo de Barcelona, págs. 304-306.

- Comunicado sobre la historia de España por Carlos Romey, págs. 306-307.

- Manresa, págs. 307-308.

- La catedral de Córdoba, pág. 309.

- Filosofía. Carácter de nuestra época, págs. 310-316.

- Miscelánea. Manuscrito encontrado en una casa de Orates, págs. 317-319.

- Berzelius, págs. 319-324.

- Bosquejo de la poesía española anterior al siglo de Carlos V de Austria, págs. 324-330.

- Diario de un médico. Agonía de un sabio, págs. 330-339.

- George Washington, págs. 329-349.

- Artistas célebres de nuestra época. John Flarman, págs. 349-359. 
- Estudios morales. Huard y Verduron, Parte I, Capítulos I-VII, págs. 359-377.

- Furió, Antonio, Jorge Bosch, págs. 377-378.

- Ingleses y franceses, págs. 379-381.

- Shakespeare, págs. 381-389.

- Placeres levantinos, págs. 390-395.

- Ingenios contemporáneos. Hugo Fóscolo, págs. 396-400.

- El Ángel de los Williams, págs. 400-420.

- Ignacio de Loyola, págs. 421-431.

- Sepulcro cerca de Manresa, pág. 431.

- Simón de Bolivar. Historia contemporánea, págs. 432-436.

- Romani, Félix, Vanina de Ornano, pág. 437-442.

- A los suscriptores al Museo de familias. Aviso importante, págs. 443-445.

- Nápoles. págs. 445-446.

- Civilización primitiva y civilización actual del nuevo mundo, págs. 446-452.

- Viajes. Aventuras y desdichas de Francisco Burgett, págs. 452-465.

- Ciencias físicas. Noticia sobre el daguerrotipo, págs. 465-471.

- Historia contemporánea. Sublevación del Cairo, págs. 472-478.

- Diario de un médico. La niña mimada. La muerte en el tocador, págs. 478-480.

- Zschokke, Enrique, Literatura alemana. El muerto desposado, págs. 480-483.

- Bover, Joaquín María, Descripción de la milagrosa gruta de Son Lluis en la isla de Mallorca, págs. 484-485.

- Valmore, Marceline (Desbordes), Un cuento para los niños. La escuela. Los nadadores, págs. 486-489.

- Richter, Jean Paul, Literatura alemana. El sueño de una pobre loca, págs. 490-493.

- Campaña en arabia de un oficial europeo, págs. 493-499.

- Historia contemporánea. José Bonaparte, págs. 500-511.

III- Vol. III, 1840

- Al público. Los editores del Museo de Familias. Aviso importante, págs. 2-3. 
enero $1840, n^{\circ} 15$

- I. El Museo de familias o Revista Universal, 15 de enero de 1840. De los medios más adecuados para fomentar la instrucción de las clases jornaleras, págs. 7-14.

- III. Ciencias-Bellas Letras. El daguerrotipo, págs. 14-15

- II. Boletín académico. Academia de Ciencias Naturales y Artes de Barcelona, Sesión de 25 de octubre de 1839, págs. 15-28.

- IV. Filosofía y amena literatura.

- Diario de un médico. El Falsario, págs. 28-34.

- Gimnastica moderna, págs. 35-44.

- Artes y oficios. Fábricas, págs. 44-45.

- Artes químicas, pág. 45.

- Colores-tintes. Receta para blanquear la cola fuerte, págs. 45-46.

- Artes litológicas a la mecánica, págs. 46-47.

- Agricultura. Instrucción de los trabajos que se hacen por todo el año en los campos, huertos y jardines. Enero, pág. 47-49.

- VI. Historia. Geografía y viajes. Excursión en los Estados Unidos, págs. 49-54.

- VII. Biografía. Registro Necrológico.

- Carlos I, págs. 56-58.

- A. P., Don Antonio Sandalio de Arias, págs. 58-61.

- VIII. Boletín Bibliográfico. Bibliografía española, págs. 61-64.

febrero $1840, n^{\circ} 16$

- I. Ventajas del estudio de la economía política, págs. 65-67.

- II. Boletín Académico, Academia de Ciencias Naturales y Artes de Barcelona. Academia de Buenas Letras de Barcelona. Academia Sevillana de Buenas Letras. págs. págs. 69-71.

- III. Ciencias-Bellas Letras.

- El Diorama. págs. 71-74.

- Furió, Antonio, «Monumento erigido al marqués de la Romana», págs. 74-77

- IV. Filosofía y amena literatura. Huida de un francés, prisionero en Inglaterra, págs. 77-98.

- V. Artes y oficios. Fábricas.

- Economía doméstica, pág. 98.

- Artes químicas, pág. 98.

- Proceder para unir o pegar la porcelana rota, pág. 99. 
- Agricultura. Instrucción de los trabajos que se hacen por todo el año en los campos, huertos y jardines. Febrero, pág. 101-104.

- VI. Historia. Geografía y viajes.

- Romey, Charles, Sitio y toma de Barcelona en 804 por los franco-aquitanos, págs. 103-106.

- El juramento del Bajá, págs. 110-118.

- VII. Biografía. Registro Necrológico. Goethe, págs. 118-127.

- VIII. Boletín Bibliográfico, págs. 127-128.

marzo $1840, n^{\circ} 17$

- Sobre la utilidad de la educación clásica, págs. 129-131.

- Ciencias. Higiene, págs. 131-135.

- Astronomía. La tierra vista desde la luna. Del día y la noche en la superficie de la luna, pág. 135-138.

- Filosofía y amena literatura. El farol de julio, págs. 138-145.

- Escenas irlandesas. Los oranjistas, págs. 146-152.

- Geografía y viajes.

- Isleños de la Polinesia, págs. 152-162.

- La peste a bordo del bergantín del Espíritu Santo, págs. 163-172.

- Biografía.

- La Santa Flecha, por Zurbarán, págs. 172-173.

- Zacarías Werner, págs. 174-182.

- Artes y oficios. Fábricas, págs. 182-190.

- Boletín Bibliográfico, págs. 190-192.

abril $1840, n^{\circ} 18$

- Civilización entre antiguos y modernos, págs. 193-201.

- Filosofía y amena literatura. Diario de un médico. Intriga y furor, págs. 202-211.

- Viajes. Quince días en Palestina, págs. 212-216.

- Ciencias. Una palabra a nuestros lectores, págs. 216-221

- Cuadro de costumbres.

- El casamentero, págs. 222-229.

- El ventrílocuo, págs. 229-231.

- Thorvalsen, págs. 232-235.

- Ciencias médicas. De la apoplegia, págs. 235-238.

- Biografía.

- El P. Canellas, págs. 239-240. 
- Fenelon, págs. 241-249.

- Reseña de los trabajos agrícolas y hortícolas en el mes de abril, págs. 249-251.

- Bibliografía, págs. 251-252.

[mayo 1840, $n^{\circ} 19$ ]

- Colección de memorias del socio Agustín Yañez, leídas en varias sesiones de la Academia de Ciencias de Barcelona sobre la temperatura de dicha ciudad, págs. 252-262.

- Biografía. Broussais, págs. 264-267.

- Diario de un médico. La esposa, págs. 267-282.

- Viajes. Senegambia, págs. 283-291.

- Historia y monumentos de Córdoba, págs. 292-296.

- Ciencias. Química, págs. 296-302.

- Higiene, Vestidos. Sueño, págs. 302-306.

- Reseña de los trabajos agrícolas y hortícolas en el mes de mayo, págs. 306-308.

[junio 1840, $n^{\circ} 20$ ]

- Estudios morales. Un episodio de la guerra de Santo Domingo, págs. 308-320.

- Del cultivo de los pantanos y terrenos baldíos, págs. 320-328

- Historia Natural, Consideraciones generales. División de la Historia natural en varias ramas...., págs. 329-337.

- Reseña de los trabajos agrícolas y hortícolas en el mes de junio, págs. 337-339.

- González de Reguero, Vicente, Epítome histórico de la vida de Rodrigo Díaz de Vivar, págs. 340-351.

- Romance I, II, III, págs. 351-353.

- Bisso, J., Idea sobre el origen e historia de la medicina, págs. 353-355.

- Biografía.

- Rubens, págs. 356-358.

- La Bella Fornarina, págs. 358-362.

- El tribunal supremo, págs. 362-365.

- El escultor de agradecido, págs. 364-366.

- Diario de un médico. El perro fantasma, págs. 366-370.

- Filosofía. De la popularidad entre antiguos y modernos, págs. 371-376. 
- Progreso, estado actual y porvenir de las fábricas de algodón en Inglaterra, págs. 376-382.

IV- Vol. IV, 1840

- Los editores del Museo de las Familias, 1 de julio de 1840, pág. 6.

- Diario de un médico. El corazón traspasado, págs.7-10.

- Comparación entre las literaturas de los diversos países del globo, págs. 15-17.

- Higiene, págs. 18-20.

- Misceláneas. Memorias autobiográficas de una familia malaya, págs. 21-24.

- Ojeada política y comercial sobre la cuenca del Mediterráneo, págs. 24-28.

- Medicina. De la erisipela, págs. 28-30.

- Reseña de los trabajos agrícolas y hortícolas en el mes de julio, págs. 30-32.

- Ensayo sobre Lavater y su sistema fisiognómico, págs. 32-39.

- Estudios morales. La hija del general, págs. 39-49.

- La caza del lobo, págs. 41-42.

- Romance IV, V, VI, VII, págs. 31-34.

- Un episodio. De la peste en Londres en 1665, págs. 55-59.

- Una hora de sobras, págs. 59-61.

- Viajes. Escenas de un invierno en las orillas del Misisipi, págs. 62-69.

- Diario de un médico. Los primeros afanes, págs. 69-81.

- Ojeada política y comercial sobre la cuenca del Mediterráneo, págs. 81-89.

- Costumbres de las Universidades de Alemania, págs. 89-102.

- Del comercio de opio con la China, págs. 102-106.

- Reseña de los trabajos agrícolas y hortícolas en el mes de agosto, págs. 106-107.

- Comparación de la mortalidad entre célibes y casados, págs. 108-109.

- Misceláneas. Un seguro marítimo, págs. 110-114.

- Romance VIII, IX, X, XI, XII, págs. 115-120.

- Filosofía. Moral. Los abolicionistas en los Estados Unidos, págs. 120-124.

- Literatura. Biografía.

- Don Telesforo de Trueba y Cosío, pág. 125.

- Monthyon, pág. 126.

- Franklin, págs. 127-136.

- Juicio sobre el trágico alemán, págs. 136-138.

- Reseña de los trabajos agrícolas y hortícolas en el mes de septiembre, págs. 138-140. 
- Diario de un médico. Un erudito frustrado, págs. 140-146.

- Geología. Su definición y división de la tierra. Ideas generales, págs. 147-153.

- Medicina. Instrucción popular acerca de los socorros que se han de emplear con los ahogados y sofocados, págs. 153-157.

- Viajes. Una excursión a Santa Elena, págs. 158-160.

- Biografía. Dupuytren, págs. 161-162.

- Roberto Boyle, págs. 162-164.

- Francisco Bacon, págs. 165-168.

- Costumbres. El album de Waterloo, págs. 168-171.

- Misceláneas. La loca de Ostende, págs. 171-173.

- Romances del Cid Campeador. Romance XIII, XIV, XV, XVI, XVII, págs. 174-179.

- Bellas artes. Progreso y decadencia de la pintura en España, págs. 179-190.

- El amante de la emperatriz, págs. 190-193.

- Economía política. De la coligación de los jornaleros y de su influjo en la riqueza social, págs. 193-205.

- Diario de un médico. El lastimado por un espectro, págs. 203-215.

- Las mujeres en Italia, págs. 215-221.

- Reseña de los trabajos agrícolas y hortícolas en el mes de octubre, págs. 221-223.

- Romances del Cid. Romance XVIII, XIX, XX, XXI, págs. 224-229.

- Conor O’Mara. Tradición irlandesa, págs. 229-235.

- Zoología. Indagaciones sobre la aparición de los mamíferos en el globo, págs. 235-237.

- Inauguración de la estatua de Gutenberg en Maguncia, pág. 238.

- Higiene de la leche, págs. 239-242.

- Carta de Mr. Victor Cousin. Profesor de filosofía al Conde de Montalivet. Instrucción general para los maestros de las escuelas populares, págs. 239-242.

- Los dos millonarios. Cuentos morales de Zschokke, traducción del alemán, págs. 250-264.

- Reseña de los trabajos agrícolas y hortícolas en el mes de noviembre, págs. 265-266.

- Ciencias médicas. Influencia perjudicial de las tareas intelectuales de los niños en su organización y salud, págs. 264-267.

- Diario de un médico. La cabeza al revés, págs. 267-274.

- El canónigo con dos conciencias, págs. 274-280. 
- Revaux, Consideraciones generales sobre la historia natural, págs. 280-289.

- La acrópolis de Atenas, págs. 290-291.

- Romances del Cid. Romance XXII, XXIII, XXIV, págs. 291-295.

- Literatura italiana. Silvio Pellico, págs.295-300.

- Historia de los piratas y de la piratería, págs. 300-307.

- Estadística médica. Duración comparada de la vida en el hombre y en la mujer, págs. 308-310.

- Antropología. Estado social de los habitantes de la Oceanía, págs. 311-318.

- Progresos y desarrollo de la filosofía y de las ciencias metafísicas desde el principio del siglo XIX, págs. 318-328.

- Revaux, Consideraciones generales sobre la historia natural. Artículo segundo, págs. 328-337.

- Consideraciones nuevas sobre la constitución geológica de Europa, págs. 337-344.

- Los dos millonarios. Cuentos morales de Zschokke, traducción del alemán, págs. 346-360.

- Reseña de los trabajos agrícolas y hortícolas en el mes de diciembre, págs. 360-361.

- Bibliografía española. La historia del Emperador Napoleón. Biblioteca infantil, págs. 361-365.

- La vieja doncella de Boston. Leyenda americana, págs. 366-370.

- Romances del Cid. Romance XXV, XXVI, XXVII, págs. 371-374.

- Historia del drama, págs. 374-383.

V- Vol. V, 1941

- Diario de un médico. El cáncer, págs. 5-8.

- Paleografía. De los libros y manuscritos antes y después del descubrimiento de la imprenta, págs. 8-19.

- Consideraciones generales sobre la historia natural. Artículo Tercero: Mamíferos con cuatro manos (quadrumana), págs. 19-26.

- El cerrajero de Filadelfia, págs. 26-32.

- Economía Política. Influencia de la industria en el aumento de la población, págs. 33-36.

- Biografía. Antonio Barnave, págs. 36-39.

- Amor, págs. 42-48.

- El Cid. Romances XXIX-XXXII, págs.49-52.

- Vista interior de la mezquita de Achmet de Constantinopla, págs. 53-54. 
- Economía política. De la esclavitud, su origen y resultados en los pueblos antiguos y modernos (1), págs. 56-70.

- Bellas artes. Apuntes sobre una nueva especie de voz cantada, págs.71-73.

- Episodios de la vida de un naturalista. Aventuras, descripciones y escenas de la naturaleza (I), págs. 74-80.

- Costumbres-Tradiciones. Antigüedad del carnaval, o saturnales antiguas y modernas, págs. 80-84.

- Ciencias Naturales. La alquimia y la piedra filosofal, págs. 84-95.

- Escenas de la vida marítima. Un crucero en frente de la isla de cuarzo, págs. 95-98.

- Costumbres religiosas. Entierros entre los turcos, págs. 98-100.

- Psicología. Cuadro filosófico de los progresos del magnetismo animal desde Mesmer hasta el día, págs. 99-107.

- Consideraciones generales sobre la historia natural. Artículo IV. Mamíferos volátiles (chiroptea), págs. 407-416.

- Romances del Cid. XXXIII-XXXVIII, págs. 117-121.

- Costumbres. El Serrallo del hajá de Vidín, págs. 122-129.

- Viajes. Los cantones de la Suiza central, págs. 132-140.

- Consideraciones generales sobre la historia natural. Artículo quinto, págs. 140-154.

- Historia de Haiti. De sus revoluciones e importancia actual, págs. 155-159.

- Arqueología. De la fabricación y comercio de libros en la antigua Roma, págs. 160-162.

- Lady Blessington, Dos meses de matrimonio, págs. 162-171.

- Romances del Cid. XXXIX-XL, págs. 174-177.

- Costumbres indias. Los muertos vivos, págs. 178-181.

- Embriaguez, págs. 182-183.

- Casas de hierro fundido, págs. 184-185.

- Influencias de la pasión del juego en la salud, pág. 185.

- Historia. Expedición marítima hecha por los españoles en el siglo XV en las costas de Francia e Inglaterra, págs. 186-192.

- Literatura. Poetas alemanes del siglo XIX, págs. 193-204.

- Consideraciones generales sobre la historia natural. Artículo sexto, págs. 204-214.

- Filosofía religiosa. Lutero y la reforma, págs. 214-229.

- Viajes. Bellas artes, Recuerdos de Roma, págs. 227-230.

- Romances del Cid. XLI-LIV, págs. 231-234.

- Viajes. Estadística. Puerto Rico, su colonización y progresos, págs. 238-250. 
- M. Bocous, Ojeada histórico-crítica sobre la Literatura italiana, traducida del francés, anotada, y aumentada con un suplemento, págs. 250-266.

- Viajes. Costumbres. La ciudad y la Corte de San Petersburgo, págs. 268-279.

- Costumbres. Vida comercial e industrial de los habitantes de Roma, págs. 279-284.

- Consideraciones generales sobre la historia natural. Artículo séptimo, págs. 284-293.

- Estadística. Bibliografía. De la imprenta en el siglo XV, y de la propagación de este arte por las varias partes del mundo, págs. 293-303.

- J. M. de F., La Pléyada española o los siete prohombres. págs. 303-310.

- Romances del Cid. XLV-XLVI, págs. 311-316.

- Un matrimonio de la mano izquierda, págs. 316-325.

- Economía social. Política. Religión. Los socialistas ingleses. Esfuerzos y progresos de la secta owenita en Inglaterra, págs. 326-332.

- Consideraciones generales sobre la historia natural. Artículo octavo, págs. 332-346.

- Política. Filosofía. Progreso, Variedades y Porvenir de la democracia en Europa y América, págs. 346-354.

- Filosofía. Educación. De las Universidades de la Alemania y de la enseñanza superior en diferentes países de Europa, págs. 354-367.

- J. LL., Ojeada histórico-crítica sobre la Literatura italiana, traducida del francés, anotada, y aumentada con un suplemento, págs. 367-375.

- Romances del Cid Campeador, XLV, III-L, págs. 376-382.

- El Verídico, Fenómeno intelectual, págs. 382-383.

\section{Literatura, historia y pensamiento. Índice temático del museo de} familias $^{10}$

\section{Antigüedades, sitios, monumentos}

1- Vol. I, 1838: Mosaico de la iglesia de San Miguel en Barcelona, pág. 59. Sepulcro de Escipión en Tarragona, pág. 60. -Baños que existían en Barcelona en la calle del mismo nombre, pág. 94. -Arco de Bará, cerca de Tarragona, pág. 122.-Puente del diablo y arco triunfal cerca de Martorell, pág. 186. -Sala capitular del monasterio de Poblet, pág. 197. -Anfiteatro de Tarragona, pág. 384

10. Reproducimos original del índice temático en las materias relativas a cultura humanística. 
II- Vol. II, 1839: -Bajo relieve del claustro de la catedral de Tarragona, pág. 50. -Ciencias naturales. Escenas de la vida de un naturalista, págs. 51-62. -La Alhambra, págs. 63-64. -San Miguel Desfal, págs. 118-119. -Vista de Monistrol y de la montaña de Montserrate, págs. 250-251. -Manresa, págs. 307-308. -La catedral de Córdoba, pág. 309. -Sepulcro cerca de Manresa, pág. 431. -Nápoles. págs. 445-446.

\section{Bellas artes}

IV- Vol. IV, 1840 : -Progreso y decadencia de la pintura en España, págs. 179-190.

\section{Biografía}

I- Vol. I, 1838: Don Juan de Austria, págs. 371-372.

II- Vol. II, 1839: -Miguel de Cervantes Saavedra, págs. 30-32. -Ingenios contemporáneos. D. Vicente Cuyás, págs. 48-49. -Murillo, págs. 117-118. -El Taso, pág. 181-190. -Schiller, págs. 239-241. -George Washington, págs. 329-349. -Potencias intelectuales y nuestra edad. Humphrey Davy, págs. 267272. -Biografía. Vida y aventuras de Trelawney, amigo de Lord Byron, págs. 272-281. -Berzelius, págs. 319-324. -D. Guillermo Mesquida, págs. 302-303. -Artistas célebres de nuestra época. John Flarman, págs. 359. -Jorge Bosch, págs. 377-378. -Shakespeare, págs. 381-389. -Ingenios contemporáneos. Hugo Fóscolo, págs. 396-400. -Ignacio de Loyola, págs. 421-431. -Simón de Bolivar. Historia contemporánea, págs. 432-436.

III- Vol. III, 1840: -Carlos I, págs. 56-58.-A. P., Don Antonio Sandalio de Arias, págs. 58-61. -Goethe, págs. 118-127. -La Santa Flecha, por Zurbarán, págs. 172-173. -Zacarías Werner, págs. 174-182. -Thorvalsen, págs. 232-235. -El P. Canellas, págs. 239-240. -Fenelon, págs. 241-249. -Broussais, págs. 264-267. -Rubens, págs. 356-358. -La Bella Fornarina, págs. 358-362.

IV- Vol. IV, 1840 : -Literatura. Biografía. -Don Telesforo de Trueba y Cosío, pág. 125. -Monthyon, pág. 126. -Franklin, págs. 127-136. -Dupuytren, págs. 161-162. -Roberto Boyle, págs. 162-164. -Francisco Bacon, págs. 165-168.

V- Vol. V, 1841: -Antonio Barnave, págs. 36-39. -Filosofía religiosa. Lutero y la reforma, págs. 214-229. 


\section{Cuadros de costumbres}

I- Vol. I, 1838: -Costumbres Inglesas. El regreso del Nabá, págs. 33-46. -Don Juan, págs. 84-94. -El Soldado ruso y la joven armenia. Anécdota contemporánea, págs. 96-107. -Edad Media española. Bernardo del Carpio, págs. 107114. -La lonja de Londres, págs. 128-135. -El utilizador. Anécdota americana, págs. 174-177. -Historia de las sectas religiosas. Los cuaqueros. Los anabaptistas, págs. 198-206. -Costumbre húngaras. Speranski I, págs. 243-255.

II- Vol. II, 1839: -Cuadro de costumbres. Jorge de Lindsay, págs. 24-29. -Gelina, págs. 82-92. -Un matrimonio griego en Atenas, págs. 92-95. -Costumbres sicilianas, págs. 150-158. -Autobiografía. Juventud, locura y casualidad, págs. 191-201. -El casamiento chino, págs. 237-239.

\section{Diario de un médico}

I- Vol I, 1838: -Diario de un médico. El Boxer o el luchador y la Niña. págs. 153-170. -Diario de un médico. El comerciante arruinado. págs. 211-220. Desliz y arrepentimiento. págs. 290-300. -Desliz y arrepentimiento, págs. 331-339.

II- Vol. II, 1839: -La tisis, págs. 74-82. -El rico y el pobre, págs. 17-23. -¡Es loca...!, págs. 157-171. -El desafío, págs. 223-228. -La hija del comerciantes, págs. 291-301. -Agonía de un sabio, págs. 330-339. La niña mimada. La muerte en el tocador, págs. 478-480.

III- Vol. III, 1840: Ver Estudios morales.

IV- Vol. IV, 1840: -El corazón traspasado, págs.7-10. -Los primeros afanes, págs. 69-81. -Un erudito frustrado, págs. 140-146. -El lastimado por un espectro, págs. 203-215. La Cabeza al revés, págs. 267-274.

\section{Estudios morales}

I- Vol. I, 1838: -La cena en casa de un nigromántico. Imitación de un cuento alemán, págs. 123-128. -La amistad, págs. 170-174.-La caridad en el invierno, págs. 178-180.-Aventuras de una familia inglesa, págs. 222-231. -Aventuras de una familia inglesa, págs. 274-289. -Escenas de la Iglesia primitiva, págs. 300-304. -Escenas de la vida militar. Una ejecución en la isla de Malta, págs. 344-349. -El sepulcro de María, págs. 349-354. -Las dos hermanas, págs. 362-369. -Escenas irlandesas, págs. 372-378. 
II- Vol. II, 1839: -Moral. Fábricas de vicios y delitos al uso de los gobiernos. Fábricas de vicios y delitos al uso de los gobiernos (Babylon the Grese), págs. 33-41. -De las casas de refugio en los Estados Unidos, págs. 201-204.-Las consejas de Schiraz, págs. 226-337. -Huard y Verduron, Parte I, Capítulos IVII, págs. 359-377. -Viajes. Aventuras y desdichas de Francisco Burgett, págs. 452-465. -Un cuento para los niños, págs. 486-489.

III- Vol. III, 1840: Ver Estudios morales. Amena literatura.

\section{Literatura}

I- Vol. I, 1838: -Mujeres griegas, págs. 231-240.

II- Vol. II, 1839: -Supersticiones poéticas de la Escocia, págs. 214-223. -Bosquejo de la poesía española anterior al siglo de Carlos V de Austria, págs. 324-330. -El Ángel de los Williams, 400-420. -El muerto desposado, págs. 480-483. -El sueño de una pobre loca, págs. 490-493. -Vanina de Ornano, pág. 437-442.

III- Vol. II, 1840: Ver Estudios morales. Amena literatura.

IV- Vol. IV, 1840: -Comparación entre las literaturas de los diversos países del globo, págs. 15-17. -Juicio sobre el trágico alemán Schiller, págs. 136-138. -Silvio Pellico, págs.295-300. Bibliografía española. págs. 361-365. -Historia del drama, págs. 374-383.-Romances del Cid Campeador, págs. 31-34, págs. 115-120, págs. 174-179, págs. 224-229, págs. 291-295, págs. 371-374.

V- Vol. V, 1841: -Diario de un médico. El cáncer, págs. 5-8. -Paleografía. De los libros y manuscritos antes y después del descubrimiento de la imprenta, págs. 8-19. -El cerrajero de Filadelfia, págs. 26-32. -Arqueología. De la fabricación y comercio de libros en la antigua Roma, págs. 160-162. -Poetas alemanes del siglo XIX, págs. 193-204. -De la imprenta en el siglo XV, y de la propagación de este arte por las varias partes del mundo, págs. 293303. -La Pléyada española o los siete prohombres, págs. 303-310. -Ojeada histórico-crítica sobre la Literatura italiana, traducida del francés, anotada, y aumentada con un suplemento, págs. 367-375. -Romances del Cid Campeador, págs.49-52, págs. 117-121, págs. 174-177, págs. 231-234, págs. 311-316, págs. 376-382. 


\section{Estudios morales-amena literatura}

III- Vol. II, 1840: -Diario de un médico: El Falsario, págs. 28-34. -Intriga y furor, págs. 202-211. -La esposa, págs. 267-282. -El perro fantasma, pág. 366-370. -Huida de un francés, prisionero en Inglaterra, págs. 77-98. -El juramento del Bajá, págs. 110-118. -El farol de julio, págs. 138-145.-Los oranjistas, págs. 146-152. -La peste a bordo del bergantín del Espíritu Santo, págs. 163-172. -El casamentero, escenas de la vida escocesa, págs. 222-229.El ventrílocuo, págs. 229-231. -Un episodio de la guerra de Santo Domingo, págs. 308-320. -Romances del Cid, págs. 351-353. -El escultor de agradecido, págs. 364-366.

\section{Filosofía}

I- Vol. I, 1838: -Los restos de Jacob, págs. 181-185. -Influjo que ha ejercido y está ejerciendo Walter-Scott en la riqueza, la moralidad y la dicha de la sociedad moderna, págs. 354-359.

III- Vol. II, 1840: -Ventajas del estudio de la economía política, págs. 65-67. -De los medios más adecuados para fomentar la instrucción de las clases jornaleras, págs. 7-14. -Sobre la utilidad de la educación clásica, págs. 129-131. -Civilización entre antiguos y modernos, págs. 193-201. -De la popularidad entre antiguos y modernos, págs. 371-376.

\section{Historia}

I- Vol. I, 1838: -Situación del pueblo ruso desde sus orígenes hasta nuestros días, págs. 256-273.

III- Vol. II, 1840: -Sitio y toma de Barcelona en 804 por los franco-aquitanos, págs. 103-106. -El tribunal supremo, págs. 362-365.

\section{Filosofía - Historia}

II- Vol. II, 1839: -La Magia en el siglo XIX y en los anteriores, págs. 64-74. -Morris, M. G., Memorias, págs. 104-116. -Persecuciones contra el cristianismo, págs. 248-250. -Carácter de nuestra época, págs. 310-316. -Civilización primitiva y civilización actual del nuevo mundo, págs. 446-452. -Historia contemporánea. Sublevación del Cairo, págs. 472-478. 


\section{Historia, Filosofía, Moral, Política}

III- Vol. II, 1840: -Ojeada política y comercial sobre la cuenca del Mediterráneo, págs. 24-28, págs. 81-89. -Estudios morales. La hija del general, págs. 39-49. -Costumbres de las Universidades de Alemania, págs. 89-10. -De la coligación de los jornaleros y de su influjo en la riqueza social, págs. 193-205. -Una hora de sobras, págs. 59-61.-Filosofía. Moral. Los abolicionistas en los Estados Unidos, págs. 120-124. -Las mujeres en Italia, págs. 215-221. -Carta de Mr. Victor Cousin. Profesor de filosofía al Conde de Montalivet. Instrucción general para los maestros de las escuelas populares, págs. 239-242. -Antropología. Estado social de los habitantes de la Oceanía, págs. 311-318. -Los dos millonarios. Cuentos morales de Zschokke, traducción del alemán, págs. 250-264. págs. 346-360. -Historia de los piratas y de la piratería, págs. 300307. -Progresos y desarrollo de la filosofía y de las ciencias metafísicas desde el principio del siglo XIX, págs. 318-328.

V- Vol. V, 1841: -Influencia de la industria en el aumento de la población, págs. 33-36. -Amor, págs. 42-48. -De la esclavitud, su origen y resultados en los pueblos antiguos y modernos (1), págs. 56-70. -Historia de Haiti. De sus revoluciones e importancia actual, págs. 155-159. -Historia. Expedición marítima hecha por los españoles en el siglo XV en las costas de Francia e Inglaterra, págs. 186-192. -De las Universidades de la Alemania y de la enseñanza superior en diferentes países de Europa, págs. 354-367. -Los socialistas ingleses, págs. 326-332. -Progreso, Variedades y Porvenir de la democracia en Europa y América, págs. 346-354.

\section{Misceláneas}

I- Vol. I, 1838: Una caza de elefantes en las cercanías del cabo de Buena-Esperanza, págs. 118-121. -Proverbios orientales. Plutarco, Ley de Solón, pág. 186. -Pelea de dos toros en celo, pág. 187. -Barcelona, págs. 306-308. -Representaciones de Jovellanos, págs. 317-320. -Los lobos, págs. 339-344. -El último jefe de una tribu indiana. Anécdota americana, págs. 359-362.

II- Vol. II, 1839: -Los pongos, págs. 252-256. -El sepulcro de Lord Byron en Hucknall Torkard, págs. 281-284.-Comunicado sobre la historia de España por Carlos Romey, págs. 306-307. -Manuscrito encontrado en una casa de Orates, págs. 317-319. - La caverna del tigre, págs. 256-259.-Ingleses y franceses, págs. 379-381.-Campaña en Arabia de un oficial europeo, págs. 493-499. 
IV- Vol. IV, 1840: -Memorias autobiográficas de una familia malaya, págs. 21-24. -La caza del lobo, págs. 41-42. -Un episodio. De la peste en Londres en 1665, págs. 55-59. -Comparación de la mortalidad entre célibes y casados, págs. 108-109. -Un seguro marítimo, págs. 110-114. -La loca de Ostende, págs. 171-173. -Conor O’Mara. Tradición irlandesa, págs. 229-235. -Costumbres. El album de Waterloo, págs. 168-171. -El amante de la emperatriz, págs. 190-193. -El canónigo con dos conciencias, págs. 274-280. -Inauguración de la estatua de Gutenberg en Maguncia, pág. 238. -La acrópolis de Atenas, págs. 290-291. -La vieja doncella de Boston. Leyenda americana, págs. 366-370.

V-Vol. V, 1841: -Apuntes sobre una nueva especie de voz cantada, págs.71-73. -Episodios de la vida de un naturalista. Aventuras, descripciones y escenas de la naturaleza (I), págs. 74-80. -Costumbres-Tradiciones. Antigüedad del carnaval, o saturnales antiguas y modernas, págs. 80-84. -Escenas de la vida marítima. Un crucero en frente de la isla de cuarzo, págs. 95-98. -El Serrallo del hajá de Vidín, págs. 122-129. -Dos meses de matrimonio, págs. 162-171. -Costumbres indias. Los muertos vivos, págs. 178-181. -Casas de hierro fundido, págs. 184-185. -Embriaguez, págs. 182-183. -Influencias de la pasión del juego en la salud, pág. 185. -Un matrimonio de la mano izquierda, págs. 316-325. -Vista interior de la mezquita de Achmet de Constantinopla, págs. 53-54.

\section{Viajes}

I- Vol. I, 1838: -Viaje de Lima a Pará, por los Andes, las misiones y el río de las Amazonas», págs. 21-32. Terremoto en Chile, págs. 51-58. -Viaje al Polo Boreal, págs. 70-84. -Expedición proyectada en los Estados Unidos para explorar los recursos comerciales de las Islas del Mar del Sur, págs.135-142. -Viaje al Polo Boreal, págs. 142-153. -Tres días en las riberas del Orinoco, págs. 206-211. -La Maladeta. Junto a Venasque. Escenas de los Pirineos, págs. 308-317. De los viajes más recientes alrededor del mundo, págs. 320-330.

II- Vol. II, 1839: -Un invierno en Laponia, págs. 41-47.-Usos y costumbres de los chinos, págs. 128-145. -Excursión a la Meca y a la Medina, págs. 172-179. -Segunda expedición comercial a las costas de China, págs. 210-213.-La corte de Madagascar, págs. 241-245. -Los monjes del monte San Bernardo, págs. 245-247. -Bosquejos levantinos, págs. 390-395.

III- Vol. III, 1840: -Excursión en los Estados Unidos, págs. 49-54. -Isleños de la Polinesia, págs. 152-162. -Quince días en Palestina, págs. 212-216. Historia y monumentos de Córdoba, págs. 292-296. -Senegambia, págs. 283-291. 
IV- Vol. IV, 1840: -Escenas de un invierno en las orillas del Misisipi, págs. 62-69. -Una excursión a Santa Elena, págs. 158-160.

V- Vol. V, 1841: -Los cantones de la Suiza central, págs. 132-140. -Bellas artes, Recuerdos de Roma, págs. 227-230. -Costumbres. La ciudad y la Corte de San Petersburgo, págs. 268-279. -Vida comercial e industrial de los habitantes de Roma, págs. 279-284. -Puerto Rico, su colonización y progresos, págs. 238-250.

\section{Bibliografía}

ANÓNIMO. 5-12-1832. «La trompeta literaria», Revista española, 8.

Bertran i PijoAn. 1931. Premsa de Catalunya, Barcelona.

Clua Serena, José Antonio. 1987. «Bergnes de las casas, helenista del sexenio liberal español. Semblanza intelectual, Estudios clásicos, 29, 92, págs. 59-71.

COMAS I GÜELL, Montserrat. 2009. La imprenta catalana i els seus protagonistes al inicis de la societat liberal (1800-1833), Tesi doctoral, dirigida per Borja de Riquer, Barcelona, Universitat Autònoma de Barcelona, Consultado http://www. tdx.cat/bitstream/handle/10803/4821/mcgldel.pdf?sequence=1, diciembre de 2012.

DARnton, Robert. 1982. L' Aventure de l' Encyclopédie, 1775-1800. París, Seuil.

DuRÁN Y SEMPERE, Agustín. 1952. Editores y libreros en Barcelona: Estivill, Piferrer, Brusi, Bastinos, Barcelona, José Boch.

FERRER, Antoni-Lluc. 1987. La patrie imaginaire: la projection de «La Pàtria» de B.C. Aribau (1832) dans la mentalité catalane contemporaine, Aix en Provence, Publications Université de Provence.

FERRER, Antoni-Lluc. 1998. "Tres poemas inéditos del Duque de Rivas (18251833)», Mélanges offerts au professeur Guy Mercadier. Aix en Provence, Publications Université de Provence, págs. 125-148.

Freire LoPEZ, Ana María. 2005. «Un negocio editorial romántico (Aribau y Walter Scott)», Anales de Literatura Española, 18, págs. 163-180.

GonZÁlez PAlENCIA, Ángel. 1933. «Sobre El Vapor, periódico de Barcelona», Amigos de Zorrilla, Valladolid, Imprenta Castellana, págs. 17-22.

Guillamet, Jaume. 2003. Els orígens de la premsa a Catalunya. Catàleg de periòdics antics (1641-1833), Barcelona, Arxiu Municipal de Barcelona.

Huade PASCuAL, Pilar. 2006. «Bergnes de las Casas, crítico literario: entre el helenismo y el romanticismo», Marieta Cantos Casenave (ed.), Redes y espacios de opinión pública: de la Ilustración al Romanticismo: Cádiz, América y Europa ante la Modernidad, 1750-1850, Universidad de Cádiz, Alienta Editorial, págs. 237-247. 
JURETSCHKE, Hans. 1979. «La Abeja» de Bergnes de las Casas o aspectos del Germanismo catalán hacia mediados del siglo XIX, Estudis Universitaris Catalans, XXIII, págs. 313-329.

LAFARGA, Francisco. 2004. «Nombres propios en la literatura francesa en El Vapor (1833-1836)», Marta Giné Janer y Yolanda Domínguez (coord.), Premsa hispànica i literatura francesa al segle XIX: petites i grans ciutats = Prensa hispánica y literatura francesa en el siglo XIX: pequeñas y grandes ciudades, Universitat de Lleida, Edicions de la Universitat de Lleida, págs. 47-64.

LAFARGA, Francisco. 2009. «La cultura francesa en El Vapor (1833-1836): referentes franceses en el debate sobre el romanticismo; en Encarnación Medina Arjona (coord.); La prensa = La presse, Universidad de Jaén, Diputación Provincial de Jaén, págs. 31-40.

Miquel I Vergés, Josep M. 1937. La Premsa catalana del vuit-cents. Barcelona, Barcino, 2 vols., 309+308.

Olives CANAlS, Santiago. 1947. Bergnes de las Casas, helenista y editor, 18011879, Barcelona, C.S.I.C.

RUBIó y ORS, Joaquín, 1887. Noticia de la vida y escritos de D. Manuel Milá i Fontanals, Barcelona, Imprenta de J. Jesús Roviralta.

Segalá y Estalella, Luis. 1916. «El Renacimiento Helénico en Catalunya», Discurso inaugural en la apertura del Curso Académico 1915-1916 de la Universidad de Barcelona, Barcelona, Tipografía La Académica.

TORRENT, Joan y TASIS, Rafael. 1966. Història de la premsa catalana, Barcelona, Bruguera.

VALLE DE RIBAS, Marqués de [Manuel Rodríguez de Llauder]. -11-1968. «Aportación al periodismo. Unas cartas de Aribau aclaran la fundación de El Vapor». $A B C$.

VALLE DE RIBAS, Marqués de [Manuel Rodríguez de Llauder]. 26-4-1983. «Aribau, Llauder i el periódico El Vapor», El Noticiero Universal.

Fecha de recepción: 04/07/2013

Fecha de aceptación: 12/09/2013 